\title{
Study of fossil wood from the Middle-Late Miocene sediments of Dhemaji and Lakhimpur districts of Assam, India and its palaeoecological and palaeophytogeographical implications
}

\author{
R C Mehrotra*, S K Bera, S K Basumatary and G Srivastava \\ Birbal Sahni Institute of Palaeobotany, 53 University Road, Lucknow 226 007, India. \\ *e-mail:rcmehrotra@yahoo.com
}

\begin{abstract}
In order to reconstruct the palaeoclimate, a number of fossil wood pieces were collected and investigated from two new fossil localities situated in the Dhemaji and Lakhimpur districts of Assam. They belong to the Tipam Group considered to be of Middle-Late Miocene in age and show affinities with Gluta (Anacardiaceae), Bischofia (Euphorbiaceae), Bauhinia, Cynometra, Copaifera-Detarium-Sindora, Millettia-Pongamia, and Afzelia-Intsia (Fabaceae). The flora also records a new species of Bauhinia named Bauhinia miocenica sp. nov. The assemblage indicates a warm and humid climate in the region during the deposition of the sediments. The occurrence of some southeast Asian elements in the fossil flora indicates that an exchange of floral elements took place between India and southeast Asia during the Miocene.
\end{abstract}

\section{Introduction}

The Assam state, situated in the northeast corner of India, is bounded by Bhutan and Arunachal Pradesh in the north and northeast, Nagaland and Manipur in the southeast, Mizoram and Tripura in the south and Bangladesh as well as Meghalaya in the southwest and west (figure 1). Six geological groups, namely Disang (Eocene), Barail (Oligocene), Surma as well as Tipam (Miocene), Dupitila (Mio-Pliocene) and Dihing (Pliocene) are found there (Karunakaran 1974) and their detailed lithostratigraphic succession has been presented in the form of a table (table 1). The fossil wood logs are known to occur from the Tipam and Dupitila Groups and a number of them have been described from various localities of Assam (Mehrotra et al 2005). Recently, two new localities have been discovered in the Dirpai riverbeds in north Lakhimpur $\left(27.13^{\circ} \mathrm{N} ; 94.7^{\circ} \mathrm{E}\right)$ of the Lakhimpur District and Subansiri riverbeds in Dhemaji $\left(27.48^{\circ} \mathrm{N} ; 94.58^{\circ} \mathrm{E}\right)$ of the Dhemaji District of Assam. The outcrop is characterized by coarse to gritty, false bedded ferruginous sandstone and conglomerate. The upper part in the section is conglomeratic, while the lower part is sandy in nature (figure 2c) and embeds fossil wood. Till date, no plant (mega or micro) remains have been recorded from these districts which experience the predominant influence of the southwest monsoon having $73-90 \%$ relative humidity. The annual rainfall varies from 2600 to $3200 \mathrm{~mm}$, while the maximum temperature reaches up to $37^{\circ} \mathrm{C}$ during July to August and the minimum temperature goes down to $10^{\circ} \mathrm{C}$ during the month of January. About 35 fossil wood pieces which have been collected either from the section or as scattered pieces lying on the riverbeds (figure $2 \mathrm{a}-\mathrm{b}$ ), belong to the Tipam

Keywords. Tipam Group; Anacardiaceae; Euphorbiaceae; Fabaceae; palaeoclimate; fossil wood; Miocene; Assam. 


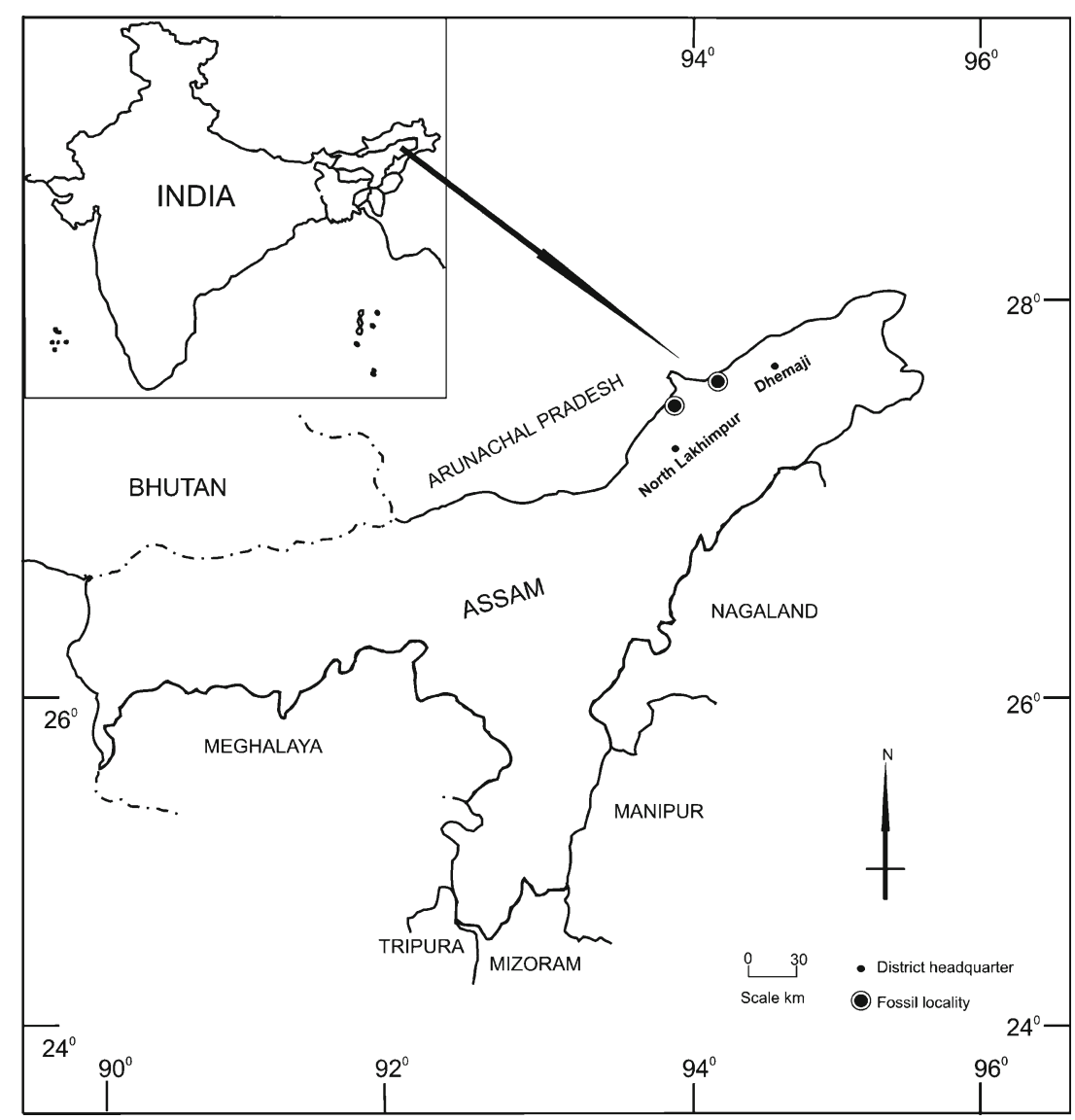

Figure 1. Map showing fossiliferous localities.

Group considered to be Middle-Late Miocene in age. These wood pieces are silicified and well preserved to reveal the structural details. Silicified wood material is the most informative mode of preservation in which molecule by molecule replacement of the original substance takes place in such a manner that even the microscopic details of the original are preserved (Schoph 1975). In order to reconstruct the palaeoenvironment of the region they have been investigated in detail and found to be of seven types, namely Glutoxylon burmense (Holden) Chowdhury of the Anacardiaceae, Bischofia palaeojavanica Awasthi of the Euphorbiaceae, Bauhinia miocenica, Cynometroxylon holdenii (Gupta) Prakash and Bande, Hopeoxylon assamicum Lalitha and Prakash, Millettioxylon pongamiensis Prakash and Pahudioxylon deomaliense Prakash of the Fabaceae.

\section{Materials and methods}

The wood material used in the present study is fragmentary varying in size from about $10-18 \mathrm{~cm}$ and collected from the bigger logs after breaking them in the field. Out of 35 samples, two were collected from the section, while the rest were picked up from the riverbeds. The samples picked up from the riverbeds belong to the same section of the Tipam Group as there is no other outcrop in the nearby areas. They are generally light yellow to dark brown in colour. Their slides were prepared by the standard method of cutting, grinding and polishing using different grades of carborundum powder and mounted in resin. Eleven of the samples were found ill preserved to reveal any structural detail. The slides as well as specimens are housed in the repository of the Birbal Sahni Institute of Palaeobotany, Lucknow (India). Terminology of wood anatomical characters follows the recommendations of the IAWA list (IAWA Committee 1989).

\section{Systematic description}

Family: Anacardiaceae

Genus: Glutoxylon Chowdhury (1934)

Glutoxylon burmense (Holden) Chowdhury (1952) (figure 3a-f)

Description: Wood diffuse porous (figure 3a). Growth rings present, delimited by thick walled fibres. Vessels mostly large but occasionally small to medium, t.d. 55-275 $\mu \mathrm{m}$, r.d. $55-495 \mu \mathrm{m}$ (sometimes it becomes difficult to measure correct r.d. 
Table 1. Generalized lithostratigraphic sequence in Assam (after Karunakaran 1974).

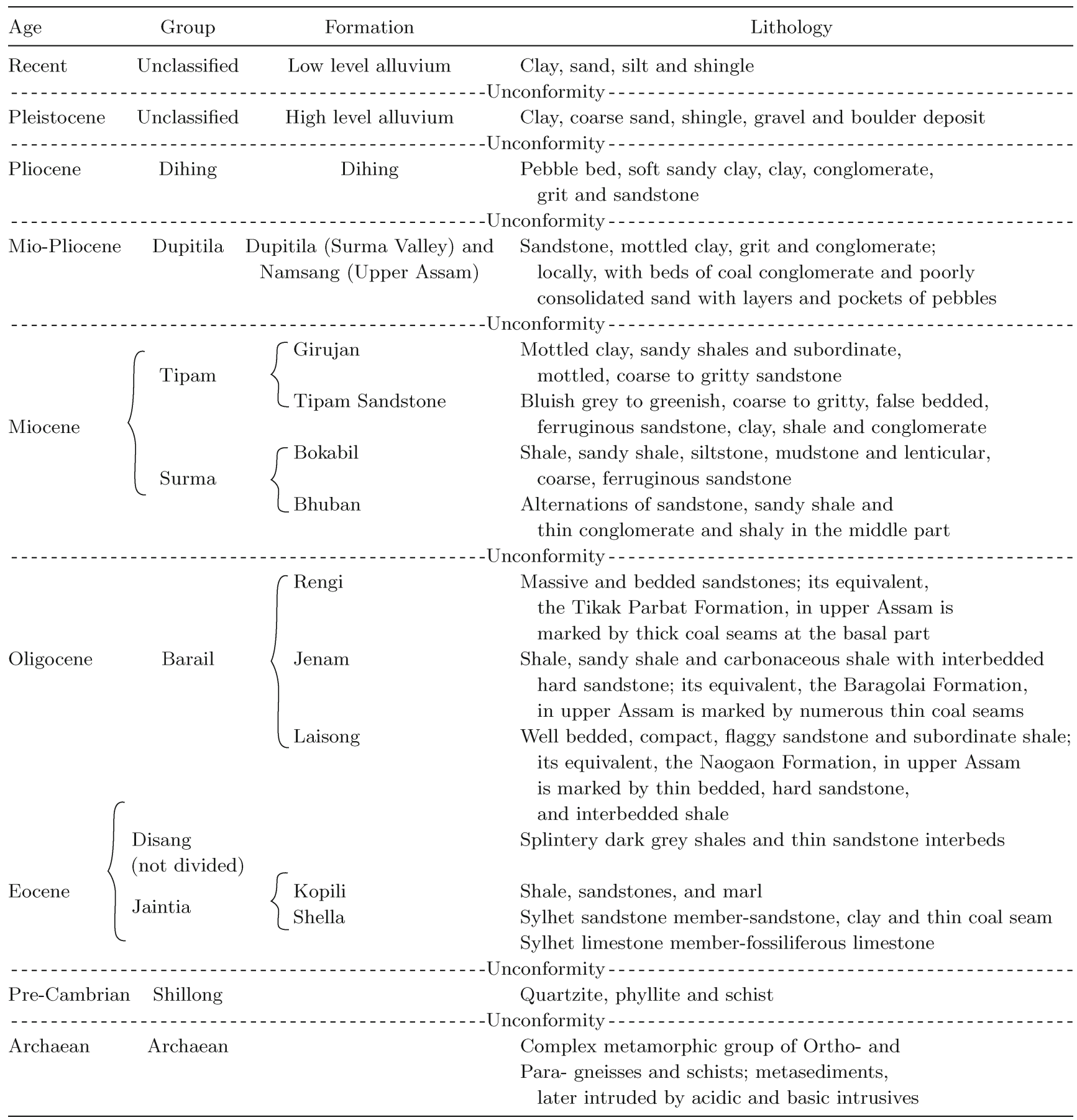

due to the presence of tyloses destroying walls of the vessels in the radial multiples), solitary and in radial multiples of $2-4$, round to oval, sometimes variously shaped due to compression, evenly distributed, 4-9 per $\mathrm{mm}^{2}$, heavily tylosed (figure $3 \mathrm{a}^{-}$ b); vessel members truncate, $80-110 \mu \mathrm{m}$ in height; perforations simple; intervessel pits ill preserved due to heavily tylosed vessels, bordered, alternate, $5-14 \mu \mathrm{m}$ in diameter, circular to oval (but appearing hexagonal due to crowding) with linear to lenticular apertures (figure 3f). Parenchyma both paratracheal and apotracheal; paratracheal scanty to thin vasicentric; apotracheal in the form of thin bands, 2-4 cells wide and 1-4 per $\mathrm{mm}$ (figure $3 \mathrm{a}-\mathrm{b}$ ); cells about $14 \mu \mathrm{m}$ in diameter and $14-28 \mu \mathrm{m}$ in height. Xylem rays $12-14$ per $\mathrm{mm}$, simple as well as fusiform, made up of procumbent cells only; simple ones uniseriate, rarely biseriate due to pairing of cells, $14-22 \mu \mathrm{m}$ in width and $5-25$ cells or $165-550 \mu \mathrm{m}$ in height; fusiform rays rare, $2-3$ seriate, containing solitary horizontal gum canal, about $110 \mu \mathrm{m}$ in width and $4-21$ cells or 300-460 $\mu \mathrm{m}$ in height (figure $3 \mathrm{c}-\mathrm{d}$ ); ray tissue homogeneous (figure 3e); ray cells crystalliferous, 

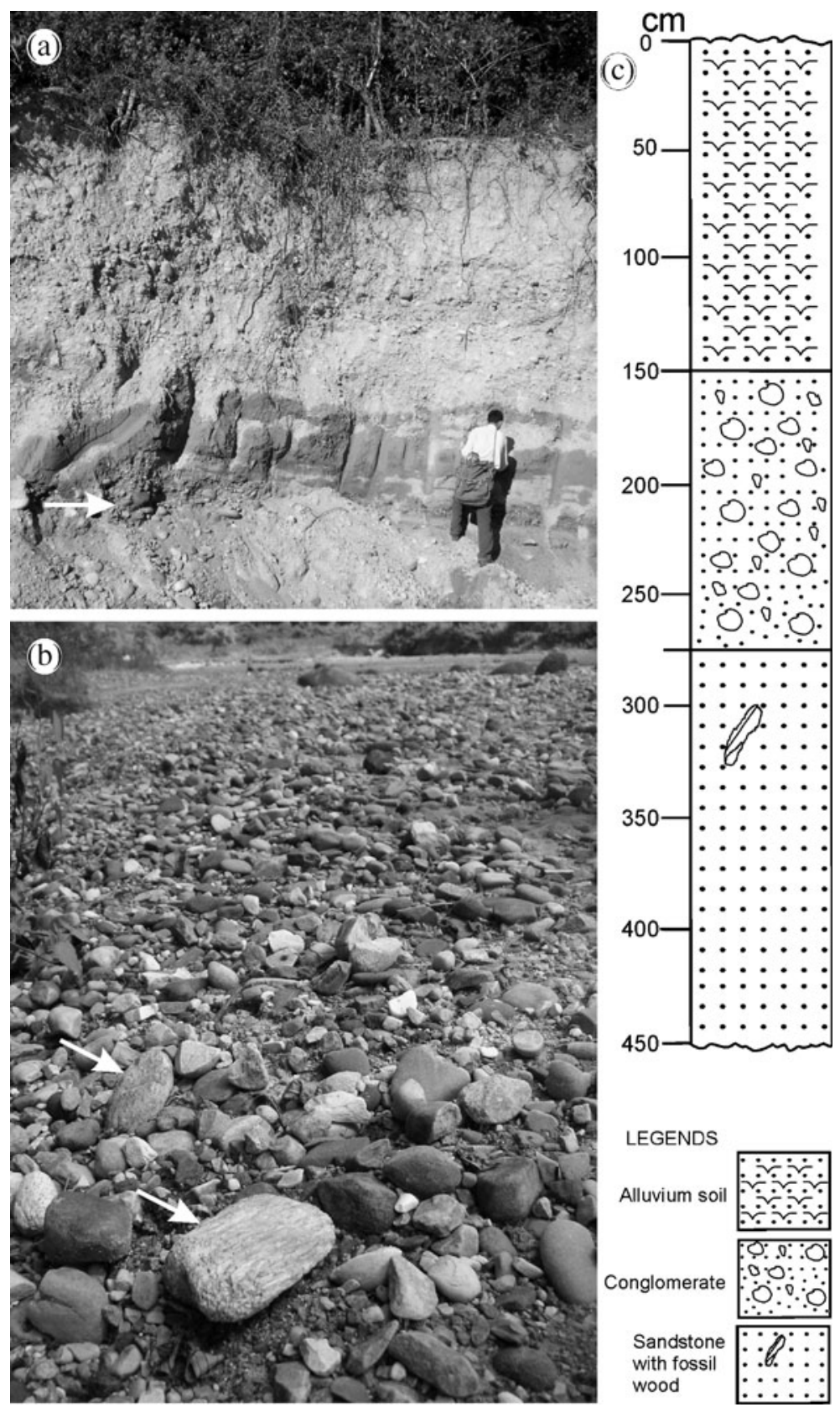

Figure 2. Field area, (a) Dhemaji section of the Tipam Group (arrow indicating wood containing zone, (b) fossil wood (marked by arrows) lying on the ground, and (c) lithostatigraphy of the fossil locality.

56-84 $\mu \mathrm{m}$ in radial length and $16-28 \mu \mathrm{m}$ in tangential height (figure 3e). Fibres angular in cross section, moderately thick walled, nonseptate, 11$19 \mu \mathrm{m}$ in diameter (figure 3b, d). Gum canals normal, horizontal, present in fusiform rays, t.d. 35-65 $\mu \mathrm{m}$ and r.d. 20-37 $\mu \mathrm{m}$ (figure $3 \mathrm{~d}$ ).

Figured specimen: Specimen no. BSIP39838.

No. of specimens: 3 .

Horizon: Tipam Group.

Locality: Subansiri riverbeds in Dhemaji, Dhemaji

District, Assam.

Age: Middle-Late Miocene.
Remarks: The diagnostic features of the fossil, viz., diffuse porous wood, mostly large vessels occluded with tyloses and radial gum canals suggest its close resemblance with the family Anacardiaceae (Ghosh and Purkayastha 1963). The occurrence of profusely tylosed vessels, simple perforation plates, thin apotracheal bands of parenchyma, predominantly uniseriate xylem rays with occasional presence of fusiform rays, homogeneous ray tissue and nonseptate fibres strongly indicate affinities with Gluta Linn. among various genera of the family (Pearson and Brown 1932; Metcalfe and Chalk 1950; Kribs 1959; Ghosh and 


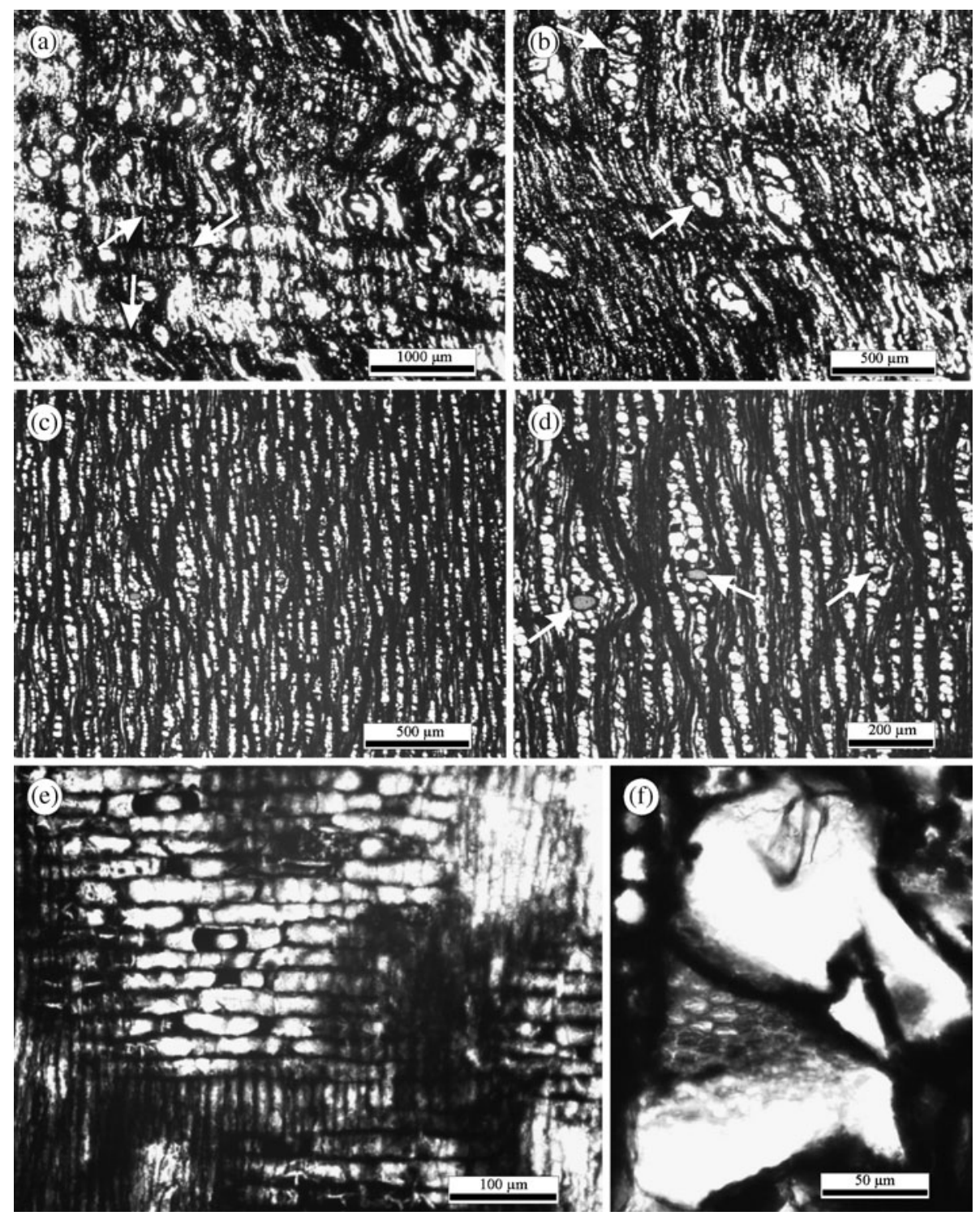

Figure 3. Glutoxylon burmense (Holden) Chowdhury, (a) diffuse-porous wood showing shape, size and distribution of vessels and parenchyma bands (marked by arrows), (b) fossil wood showing parenchyma bands and vessels plugged with tyloses (marked by arrows), (c) showing structure of xylem rays, (d) showing fusiform xylem rays having radial gum canals (marked by arrows), (e) showing homogeneous ray tissue, and (f) intervessel pits.

Purkayastha 1963; Miles 1978; Ilic 1991). Ghosh and Purkayastha (1963) have made detailed xylotomical study of various species of Gluta known from India and adjoining countries and have found that it is difficult to differentiate them on the basis of wood anatomy only. Therefore, it becomes difficult to trace the affinities of the fossil at the specific level.

Chowdhury $(1934,1936)$ for the first time erected the genus Glutoxylon (Holden) for the fossil wood resembling Gluta and those species of Melanorrhoea Wall. which have thin apotracheal bands of parenchyma. Prakash and Tripathi (1969) emended the diagnosis of Glutoxylon (Holden) Chowdhury on the basis of their study on the modern wood of Gluta and Melanorrhoea.
According to them, the fossil wood having thin apotracheal bands (usually $2-4$ cells wide) should be named Glutoxylon. They created a new genus Melanorrhoeoxylon (Prakash and Tripathi 1976) for those having thicker bands (usually 3-8 cells). Hou (1978) had merged the genus Melanorrhoea into Gluta on the basis of their taxonomic similarities. Under the circumstances, Melanorrhoeoxylon Prakash and Tripathi became invalid or superfluous to the already published Glutoxylon (Holden) Chowdhury. Therefore, Guleria (1984b) renamed two already known species of Melanorrhoeoxylon, namely M. cacharense (Prakash and Tripathi 1976) and M. garbetaense (Roy and Ghosh 1981) as G. cacharense (Prakash and Tripathi) Guleria and $G$. garbetaense (Roy and Ghosh) Guleria, respectively. 
Five valid species of the genus Glutoxylon known so far from various parts of the world are: Glutoxylon burmense (Holden) Chowdhury (1952), G. cuddalorense Awasthi (1966), G. cacharense (Prakash and Tripathi) Guleria (1984b), G. garbetaense (Roy and Ghosh) Guleria (1984b) and G. symphonoides Lemoigne (1978). Except the last one which was described from the Tertiary of Ethiopia, all other species are known from various Tertiary exposures of India (Mehrotra et al 1999). After detailed comparison with the above species, it has been found that our fossil is identical to $G$. burmense and accordingly, has been kept under the same.

Gluta of the Anacardiaceae is a genus of small to very large evergreen trees and consists of about 30 species distributed in Madagascar, India,
Myanmar, Thailand, Indo-China, China and throughout Malaysia (Ghosh and Purkayastha 1963; Hou 1978). In the Indian subcontinent it is distributed either in the coastal forests of Tenasserim, Tavoy and Mergui or in the evergreen forests of Kerala and Tamil Nadu.

Family: Euphorbiaceae

Genus: Bischofia Bl.

Bischofia palaeojavanica Awasthi (1989)

(figure $4 \mathrm{a}-\mathrm{f}$ )

Description: Wood diffuse porous (figure 4a). Growth rings absent. Vessels small to medium, rarely very small, t.d. $42-112 \mu \mathrm{m}$, r.d. $70-168 \mu \mathrm{m}$,

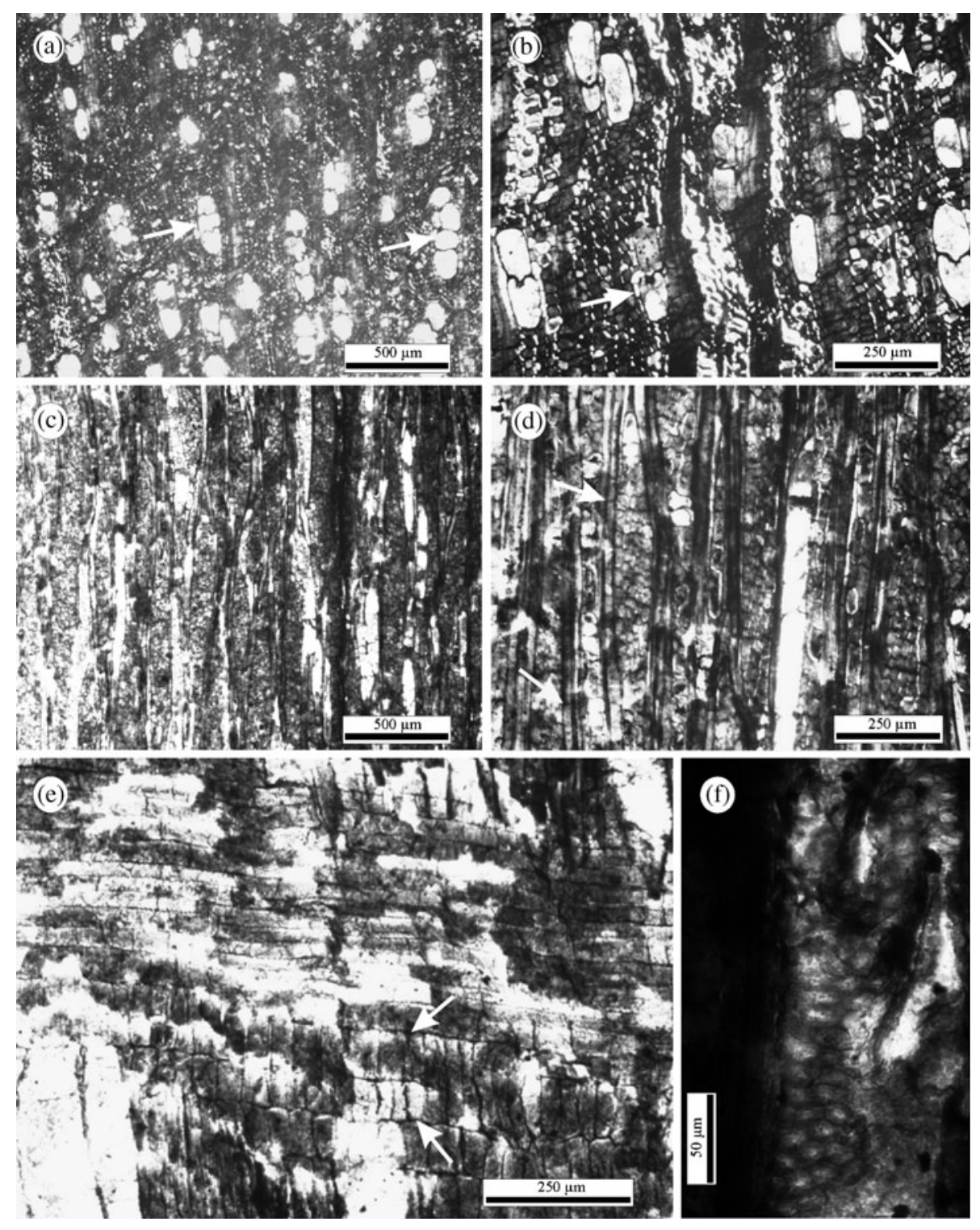

Figure 4. Bischofia palaeojavanica Awasthi, (a) diffuse-porous wood showing vessels in radial multiples (marked by arrows), (b) fossil wood showing vessels occluded with tyloses (marked by arrows), (c) showing distribution of xylem rays, (d) showing septate fibres (marked by arrows) and structure of xylem rays having crystals in some of the ray cells (marked by arrows), (e) showing heterogeneous ray tissue (arrows indicating upright cells), and (f) intervessel pits. 
solitary and in radial multiples of 2-3 (rarely 4), sometimes in tangential pairs or clusters, circular to oval, evenly distributed, 11-18 per $\mathrm{mm}^{2}$, plugged with tyloses (figure $4 \mathrm{~b}$ ); vessel members truncate, 84-238 $\mu \mathrm{m}$ in height; perforations simple; intervessel pits occasionally preserved due to tyloses, bordered, alternate, large, $8-14 \mu \mathrm{m}$ in diameter, circular to oval (appearing hexagonal due to crowding) with lenticular apertures (figure 4f). Parenchyma mostly absent, rarely 1-2 cells associated with vessels. Xylem rays $5-7$ per $\mathrm{mm}, 1-5$ seriate, uniseriates made up of upright cells, $28-36 \mu \mathrm{m}$ in width and 6-9 cells or 196-224 $\mu \mathrm{m}$ in height, multiseriates made up of procumbent cells in the median portion with 1-5 marginal rows of upright cells, $61-98 \mu \mathrm{m}$ in width and 20-72 cells or $770-2200 \mu \mathrm{m}$ in height (figure $4 \mathrm{c}-\mathrm{d}$ ); ray tissue heterogeneous (figure 4e); ray cells crystalliferous (figure $4 \mathrm{~d}$ ); procumbent cells $70-98 \mu \mathrm{m}$ in radial length and $28-42 \mu \mathrm{m}$ in tangential height; upright cells $28-56 \mu \mathrm{m}$ in radial length and 56-84 $\mu \mathrm{m}$ in tangential height (figure $4 \mathrm{e})$. Fibres angular in cross section, semilibriform, septate, crystalliferous, $27-55 \mu \mathrm{m}$ in diameter and $550-935 \mu \mathrm{m}$ in length (figure $4 \mathrm{~d}$ ).

Figured specimen: Specimen no. BSIP39839.

No. of specimens: 2 .

Horizon: Tipam Group.

Locality: Subansiri riverbeds in Dhemaji, Dhemaji District, Assam.

Age: Middle-Late Miocene.

Remarks: The diagnostic features of the fossil, viz., diffuse porous wood, simple perforation plates, restricted parenchyma and septate fibres strongly indicate its affinities with the family Euphorbiaceae (Pearson and Brown 1932). Among various genera of the family the fossil shows maximum resemblance with Bischofia Blume in having tylosed vessels, scanty paratracheal parenchyma, 1-5 seriate xylem rays and heterogeneous ray tissue (Pearson and Brown 1932; Metcalfe and Chalk 1950; Kribs 1959; Ilic 1991). Although the modern genus is represented by two species, namely B. javanica Bl. and B. polycarpa (Lévl) Airy Shaw, only the former is available for comparison. The fossil is identical to it as it shows similarities with our fossil in almost all the features.

Ramanujam (1960) erected the genus Bischofioxylon for the fossil wood similar to that of Bischofia and described Bischofioxylon miocenicum Ramanujam from south India. Mädel (1962) after suggesting its affinities with Bridelia merged it into another genus Bridelioxylon Mädel. Therefore, Bande (1974) instituted Bischofinium for the fossil wood resembling Bischofia and described B. deccanii from the Deccan Intertrappean beds of India. After the critical re-examination of the type slides of both these genera, Awasthi (1989) found that none of them belongs to Bischofia or Bridelia. While describing a fossil wood resembling Bischofia from the Namsang beds exposed near Deomali in Arunachal Pradesh, he placed his fossil directly under the extant genus and created a new species Bischofia palaeojavanica. Since then the same species has been reported from many parts of India (Awasthi and Mehrotra 1990; Agarwal 1994; Srivastava and Awasthi 1996; Guleria and Srivastava 2001; Guleria et al 2002). As our fossil is also identical to it, it has been placed under the same.

The genus Bischofia of the Euphorbiaceae consists of only two species and of which only $B$. javanica is found in India. It is a large deciduous tree widely distributed in the Indo-Malayan region ranging from the western Peninsula eastward through Myanmar and Thailand to CochinChina (South Vietnam), the Philippines, Formosa and Polynesia and southward into Malaysia (Willis 1973; Mabberley 1997). In India it occurs in Lower Himalaya up to $300 \mathrm{~m}$ and sub-Himalayan tract from the Jamuna river eastwards, through Uttar Pradesh to Bengal and Assam; southward to Bihar and Orissa, Tirunelveli and Madurai and on the west coast from Konkan to the Nilgiris.

Family: Fabaceae

Genus: Bauhinia Linn.

Bauhinia miocenica sp. nov.

(figure $5 \mathrm{a}-\mathrm{h}$ )

Specific diagnosis: Wood diffuse porous. Growth rings absent. Vessels t.d. 66-165 $\mu \mathrm{m}$, r.d. 99-302 $\mu \mathrm{m}$, solitary and in radial multiples of $2-3$ (-4), 4-8 per $\mathrm{mm}^{2}$, tyloses not observed; vessel members storied, 190-600 $\mu \mathrm{m}$ in height; perforations simple; intervessel pits bordered, alternate, about 4-7 $\mu \mathrm{m}$ in diameter, vestured. Parenchyma banded, bands regular, continuous, alternating with fibre bands, broader than fibres; cells storied. Xylem rays exclusively uniseriate, rarely biseriate, irregularly storied, made up of both procumbent and upright cells, 5-15 cells in height; ray tissue weakly heterogeneous; ray cells crystalliferous. Fibres appearing storied at places, nonseptate, $11-22 \mu \mathrm{m}$ in diameter and about $330-550 \mu \mathrm{m}$ in length. Ripple marks present due to storied vessel elements, parenchyma cells and storied rays.

Description: Wood diffuse porous (figure 5a). Growth rings absent. Vessels small to large, mostly medium, t.d. 66-165 $\mu \mathrm{m}$, r.d. 99-302 $\mu \mathrm{m}$, solitary and in radial multiples of $2-3(-4)$, round to oval, occasionally elongated, evenly distributed, 4-8 per $\mathrm{mm}^{2}$, tyloses not observed (figure $5 \mathrm{a}-\mathrm{b}$ ); vessel members truncate, storied, 190-600 $\mu \mathrm{m}$ in 


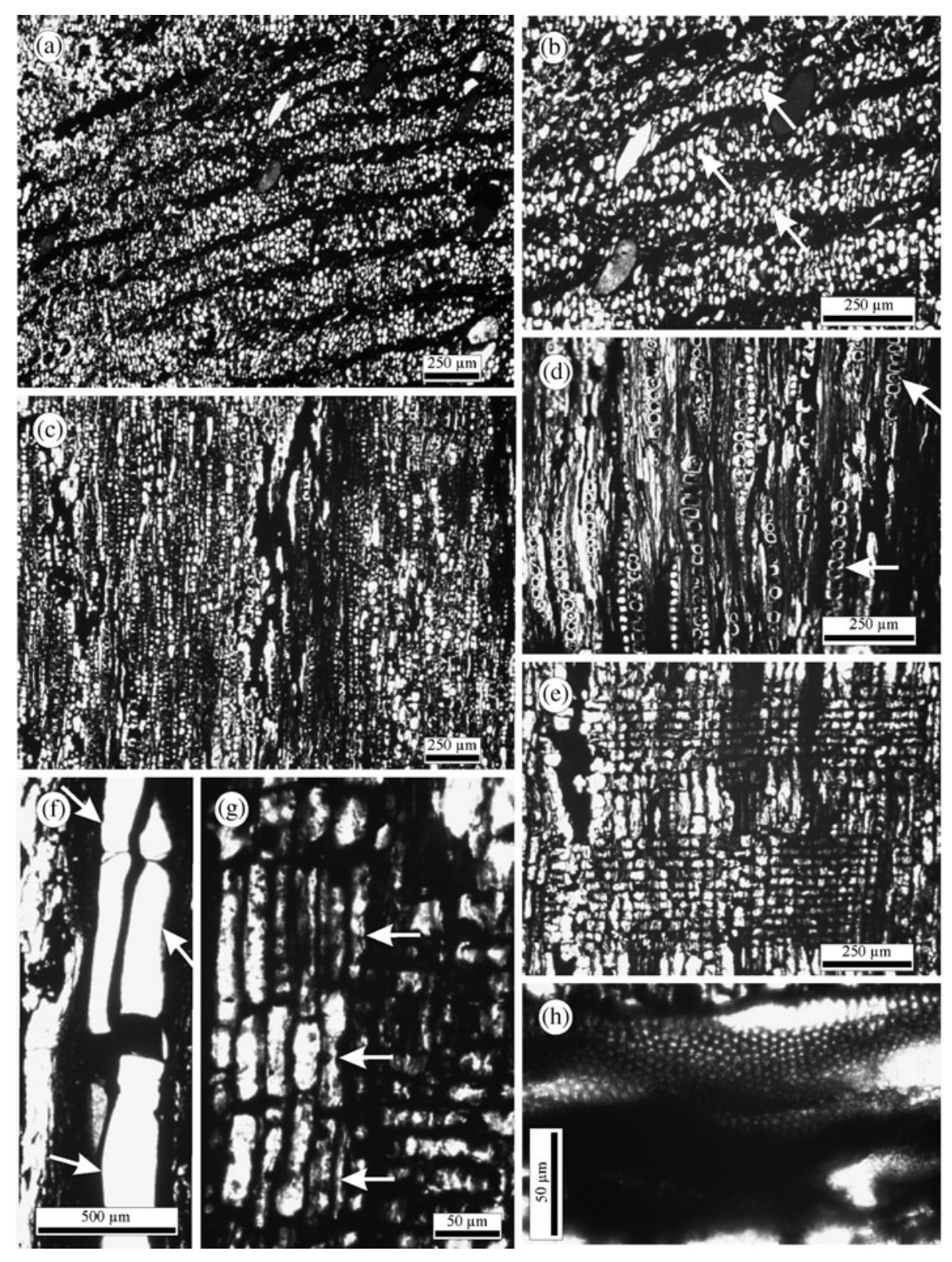

Figure 5. Bauhinia miocenica sp. nov., (a) showing shape, size and distribution of vessels and parenchyma pattern, (b) showing parenchyma bands (marked by arrows) alternating with fibre bands, (c) showing structure of xylem rays, (d) showing storied nature of xylem rays (marked by arrows), (e) showing homogeneous ray tissue, (f) storied vessel elements (marked by arrows), (g) storied parenchyma cells (marked by arrows), and (h) vestured intervessel pits.

height (figure 5f); perforations simple; intervessel pits bordered, alternate, about 4-7 $\mu \mathrm{m}$ in diameter, circular to oval, vestured (figure 5h). Parenchyma banded, bands regular, continuous, alternating with fibre bands, broader than fibres, $3-8$ cells or 135-330 $\mu \mathrm{m}$ wide (figure 5a-b); cells storied, 14$28 \mu \mathrm{m}$ in diameter and $56-140 \mu \mathrm{m}$ in height (figure $5 \mathrm{~g})$. Xylem rays $7-10$ per $\mathrm{mm}$, exclusively uniseriate, rarely biseriate, irregularly storied, made up of both procumbent and upright cells, 16-38 $\mu \mathrm{m}$ in width and $5-15$ cells or $192-550 \mu \mathrm{m}$ in height (figure $5 \mathrm{c}-\mathrm{d}$ ); ray tissue weakly heterogeneous (figure 5e); ray cells crystalliferous; procumbent cells $56-84 \mu \mathrm{m}$ in radial length and $22-42 \mu \mathrm{m}$ in tangential height; upright cells $45-47 \mu \mathrm{m}$ in radial length and 56-84 $\mu \mathrm{m}$ in tangential height (figure 5e). Fibres angular in cross section, appearing storied at places, moderately thick walled, nonseptate, $11-22 \mu \mathrm{m}$ in diameter and about $330-550 \mu \mathrm{m}$ in length (figure $5 \mathrm{~b}, \mathrm{~d}$ ). Ripple marks present due to storied vessel elements, parenchyma cells and storied rays.

Holotype: Specimen no. BSIP39840.

No. of specimens: 2 .

Derivation of name: The specific epithet is after its age (Miocene).

Horizon: Tipam Group. 
Locality: Subansiri riverbeds in Dhemaji, Dhemaji District, Assam.

Age: Middle-Late Miocene.

Remarks: The noteworthy features of the fossil, viz., diffuse porous wood, vestured intervessel pits, simple perforation plates, abundant paratracheal parenchyma, and fine xylem rays indicate its affinities with the family Fabaceae (Pearson and Brown 1932; Ramesh Rao et al 1972). Among various genera of the family, the fossil shows maximum resemblance with Bauhinia Linn. in having small to large open vessels, storied vessel elements, parenchyma cells and xylem rays, continuous and broad parenchyma bands alternating with fibre bands, almost exclusively uniseriate xylem rays and nonseptate fibres (Pearson and Brown 1932; Metcalfe and Chalk 1950; Kribs 1959; Ramesh Rao et al 1972; Ilic 1991; Gupta 2007). Ramesh Rao et al (1972) studied wood of Bauhinia from India and found that only six of its species, namely B. foveolata Dalzell, B. malabarica Roxburgh, $B$. purpurea Linn., B. racemosa Lamarck, B. retusa Hamann, and $B$. variegata Lamarck attain tree size. Except the last two where ripple marks are absent, the rest of the species are xylotomically very similar. Our fossil, having storied elements, shows similarities with these four species. Pearson and Brown (1932, p. 420) observed that in B. malabarica, middle rings of the parenchyma bands are wider than the bands of fibres and t.d. of the vessels is $<230 \mu \mathrm{m}$. As parenchyma bands in the present fossil are wider than fibre bands and t.d. of the vessels is not more than $165 \mu \mathrm{m}$, it shows maximum resemblance with the above species.

Fossil wood showing affinities with Bauhinia was first reported by Rawat (1965) from the Siwalik of Mohand (Saharanpur District) under the generic name Bauhinioxylon. The genus was not considered valid due to the absence of any description and illustration, therefore, Trivedi and Panjwani (1986) established a new genus Bauhinium for the fossil wood of Bauhinia. Awasthi and Prakash (1987) placed their fossil resembling Bauhinia directly under the modern genus. The fossil woods belonging to Bauhinia commonly occur during the Neogene in India and are: Bauhinium miocenicum (Trivedi and Panjwani 1986) and B. palaeomalabaricum (Prakash and Prasad 1984) from the Siwalik sediments of Uttar Pradesh, Bauhinia deomalica (Awasthi and Prakash 1987) from the Namsang beds of Deomali, Arunachal Pradesh and Tipam Group of Udaipur, South Tripura District, Tripura (Mehrotra et al 2006) and B. tertiara (Awasthi and Mehrotra 1990) from the Tipam Group of Mon District, Nagaland. In addition one more wood, cf. Bauhinia is described from the Cuddalore sediments of Cauvery Basin, south India
(Ramanujam and Rao 1966). After detailed comparison with all of them it has been found that the fossil shows near resemblance with $B$. palaeomalabaricum (Prakash and Prasad). However, the present fossil differs from it in radial arrangement of vessels and height of the xylem rays. As parenchyma bands are broader than fibrous bands in the present fossil, a character not observed in any of the above fossil species, it is being described as a new species, Bauhinia miocenica sp. nov.

Bauhinia is a large genus comprising about 300 species distributed throughout the tropics of the world and about 30 of its species are found in India and Myanmar. B. malabarica is a small to moderate-sized tree widely distributed in almost all the states of India, especially in the moist deciduous forests (Ramesh Rao et al 1972; Mabberley 1997).

Genus: Cynometroxylon Chowdhury and Ghosh (1946)

Cynometroxylon holdenii (Gupta) Prakash and Bande (1980)

(figure $6 \mathrm{a}-\mathrm{f}$ )

Description: Wood diffuse porous (figure 6a). Growth rings absent. Vessels small to large, t.d. 56-140 $\mu \mathrm{m}$, r.d. 56-224 $\mu \mathrm{m}$, solitary as well as in radial multiples of $2-3$, round to oval, evenly distributed, 6-12 per $\mathrm{mm}^{2}$ (figure $6 \mathrm{a}-\mathrm{b}$ ), tyloses absent but occasionally filled with dark coloured gummy deposits; vessel elements truncate, 165$465 \mu \mathrm{m}$ in height (figure 6c); perforations simple; intervessel pits bordered, alternate, 3-6 $\mu \mathrm{m}$ in diameter, circular to oval (but appearing hexagonal due to crowding) with lenticular apertures, vestured (figure 6d). Parenchyma paratracheal, in the form of broken to continuous bands, each 48 cells wide, occasionally vasicentric (figure 6ab); cells $19-28 \mu \mathrm{m}$ in diameter and $35-125 \mu \mathrm{m}$ in height. Xylem rays $7-10$ per mm, 1-3 (mostly 2) seriate, usually made up of procumbent cells, uniseriate rays $28-33 \mu \mathrm{m}$ in width and 5-6 cells or 140-196 $\mu \mathrm{m}$ in height, multiseriate rays $42-56 \mu \mathrm{m}$ in width and 13-28 cells or 308-605 $\mu \mathrm{m}$ in height (figure 6c, e); ray tissue weakly heterogeneous (figure 6f); ray cells crystalliferous; procumbent cells $56-84 \mu \mathrm{m}$ in radial length and $22-33 \mu \mathrm{m}$ in tangential height; upright/square cells $20-33 \mu \mathrm{m}$ in radial length and $28-33 \mu \mathrm{m}$ in tangential height (figure 6f). Fibres angular in cross section, thick walled, nonseptate, $5-8 \mu \mathrm{m}$ in diameter and about $500 \mu \mathrm{m}$ in length (figure $6 \mathrm{~b}-\mathrm{c}$ ).

Figured specimen: Specimen no. BSIP39841.

No. of specimens: 3 .

Horizon: Tipam Group. 


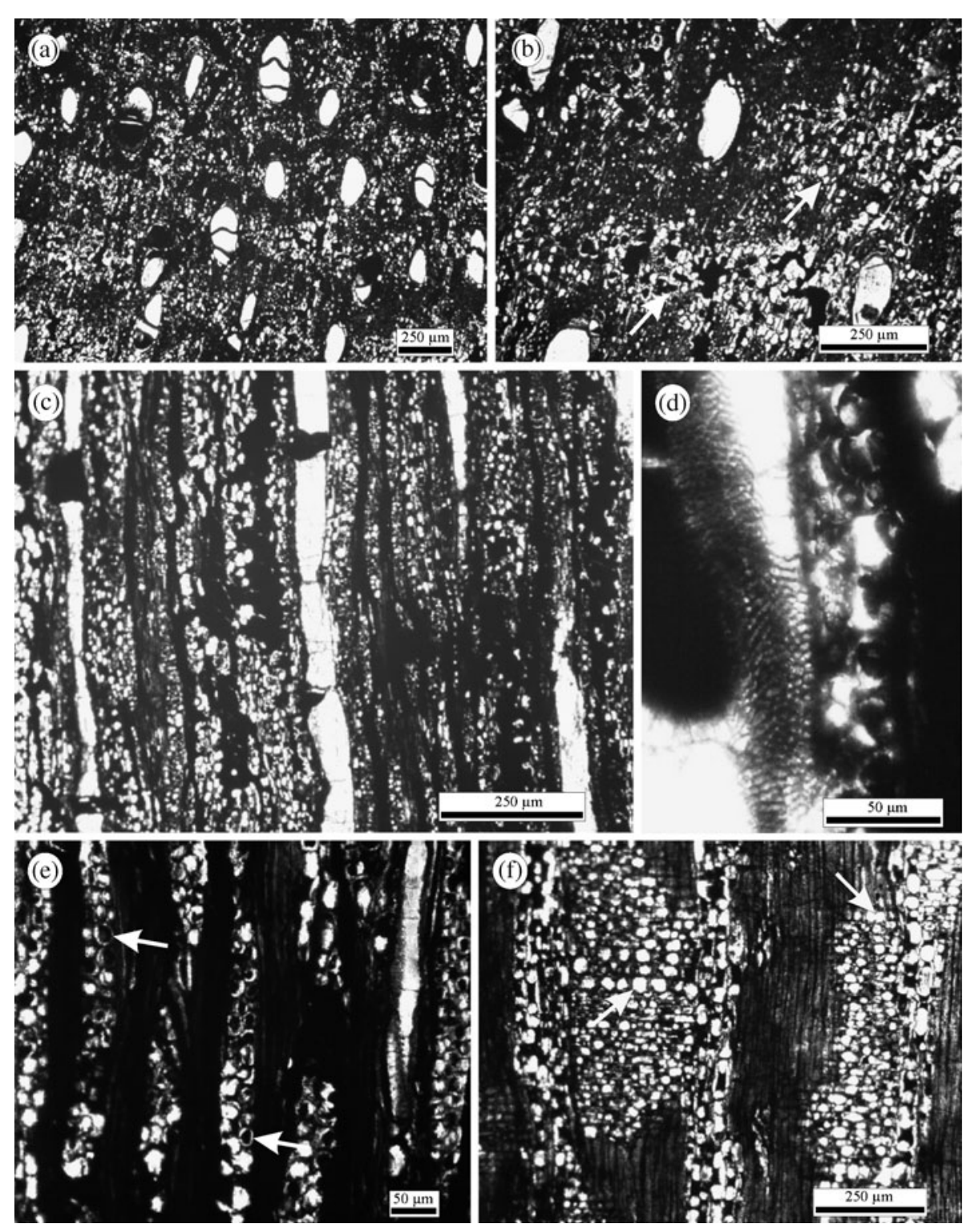

Figure 6. Cynometroxylon holdenii (Gupta) Prakash and Bande, (a) showing shape, size and distribution of vessels, (b) showing parenchyma bands (marked by arrows) alternating with fibre bands, (c) showing distribution of xylem rays, (d) intervessel pits, (e) showing structure of xylem rays (arrows indicating crystals in ray cells), and (f) showing weakly heterogeneous ray tissue (arrows indicating square/upright cells).

Locality: Subansiri riverbeds in Dhemaji, Dhemaji District, Assam.

Age: Middle-Late Miocene.

Remarks: The diagnostic features of the fossil wood, such as diffuse porous wood, banded parenchyma, simple perforation plates, vestured intervessel pits, 1-3 seriate homo to heterocellular xylem rays and nonseptate fibres indicate resemblance with Cynometra Linn., especially C. ramiflora Linn. and C. polyandra (Roxb.) Harms. of the Fabaceae (Pearson and Brown 1932; Kribs 1959; Ramesh Rao et al 1972; Ilic 1991; Gupta 2007).

Fossil wood resembling Cynometra is usually assigned to Cynometroxylon (Chowdhury and
Ghosh 1946). So far only three of its species are known from various parts of the world. C. holdenii (Gupta) (Prakash and Bande 1980) is the most commonly found species during the Neogene in India (Guleria 1992) and most of the fossil species described before 1980 have been merged with it. C. parainaequifolium (Prakash 1979a) is known from the Tertiary of Thailand, while $C$. tertiarum (Awasthi and Mehrotra 1997) is described from the Neogene of Tirap District, Arunachal Pradesh. In addition, Mehrotra et al (1999) described Cynometroxylon sp. cf. C. holdenii from the upper Tertiary sediments of Arunachal Pradesh. One of the wood fossils described from the Pleistocene of Zaire by Bande et al (1987) has directly been 
kept under the extant species Cynometra alexandri (C. H. Wright). As our fossil is similar to C. holdenii, it has been assigned to the same. The rest of the species differ from the present fossil mainly in the structure of xylem rays.

The genus Cynometra consists of about 70 species of evergreen trees or shrubs distributed in the tropics of Indo-Malayan region, Philippines, Australia, Pacific Islands, Mexico, Brazil and Africa (Ramesh Rao et al 1972; Willis 1973; Mabberley 1997). C. ramiflora is a small to medium-sized tree commonly found in the tidal forests of the Andamans and Sunderbans, while C. polyandra is a large evergreen tree found in Assam, Meghalaya and Bangladesh (Ramesh Rao et al 1972).

Genus: Hopeoxylon Navale emend. Awasthi (1977) Hopeoxylon assamicum Lalitha and Prakash (1980) (figure $7 \mathrm{a}-\mathrm{g}$ )
Description: Wood diffuse porous (figure 7a). Growth rings present, delimited by parenchyma bands enclosing the gum canals (figure 7a). Vessels small to large, rarely very small, t.d. $36-140 \mu \mathrm{m}$, r.d. $112-280 \mu \mathrm{m}$, solitary and in pairs, round to oval, sometimes elongated due to compression, evenly distributed, 12-18 per $\mathrm{mm}^{2}$ (figure $7 \mathrm{a}-\mathrm{b}$ ), tyloses absent; vessel elements truncate, 56-112 $\mu \mathrm{m}$ in height; perforations simple; intervessel pits bordered, alternate, 5-6 $\mu \mathrm{m}$ in diameter, circular to oval, vestured (figure 7e). Parenchyma both paratracheal and apotracheal; paratracheal vasicentric to aliform-confluent enclosing 2-3 neighbouring vessels (figure 7b); apotracheal in the form of tangential bands enclosing gum canals, bands 1-2 per $\mathrm{mm}$ (figure $7 \mathrm{a}, \mathrm{f}$ ); cells about $14-16 \mu \mathrm{m}$ in diameter and $22-56 \mu \mathrm{m}$ in height. Xylem rays $1-5$ seriate, 8-10 per mm, uniseriates made up of upright cells, $16-28 \mu \mathrm{m}$ in width and $7-12$ cells or $196-280 \mu \mathrm{m}$ in height; multiseriates made up of procumbent cells with 1-3 marginal rows of upright cells, 28-70 $\mu \mathrm{m}$ in width and 7-40 cells or $196-550 \mu \mathrm{m}$ in height

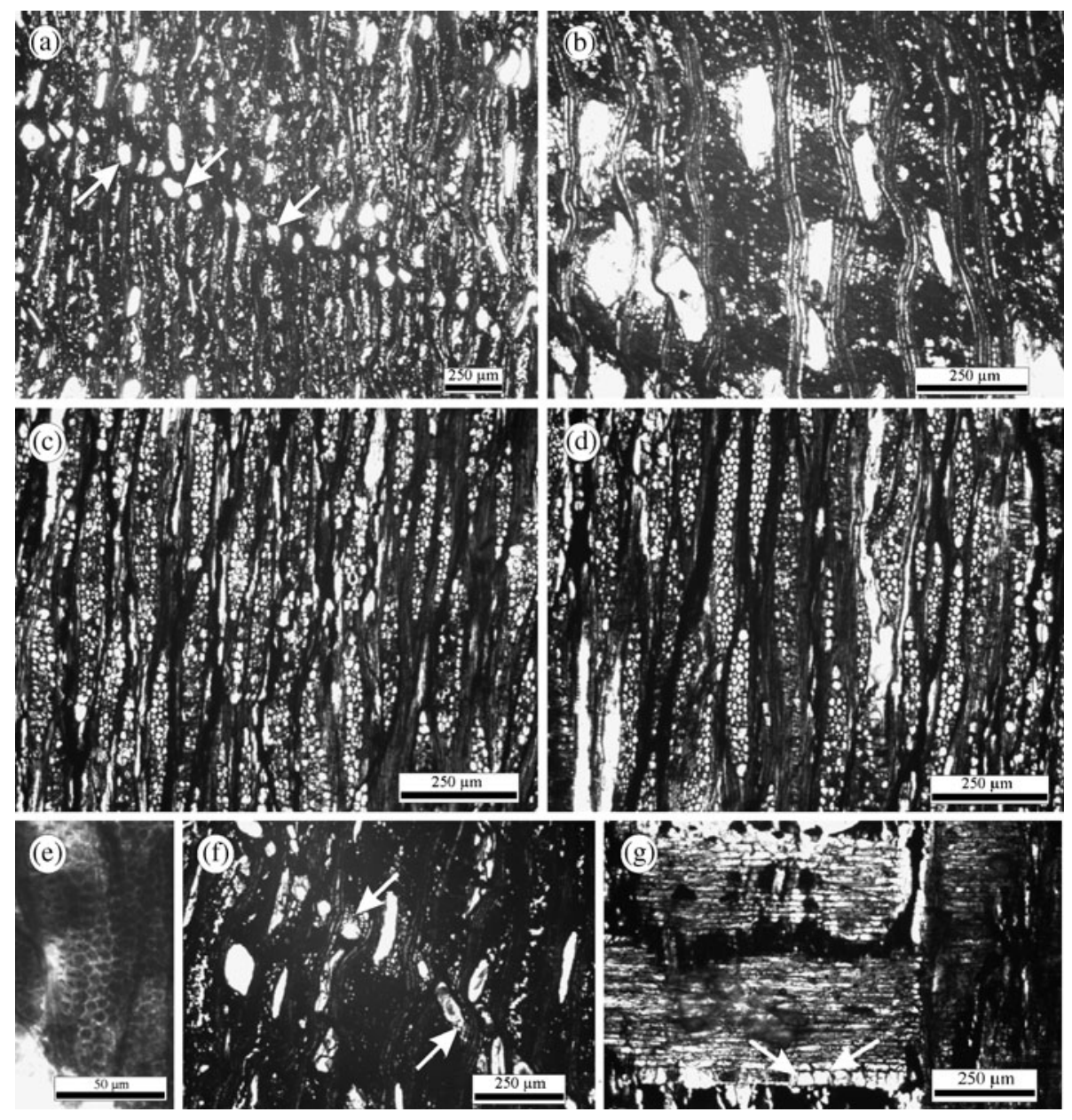

Figure 7. Hopeoxylon assamicum Lalitha and Prakash, (a) showing shape, size and distribution of vessels and gum canals (marked by arrows), (b) showing parenchyma pattern, (c) showing distribution of xylem rays, (d) showing structure of xylem rays, (e) vestured intervessel pits, (f) showing a row of gum canals enclosed in parenchyma bands (marked by arrows), and (g) showing heterogeneous ray tissue (arrows indicating upright cells). 
(figure $7 \mathrm{c}-\mathrm{d}$ ); ray tissue heterogeneous (figure $7 \mathrm{~g}$ ); ray cells crystalliferous; procumbent cells 56-90 $\mu \mathrm{m}$ in radial length and $14-28 \mu \mathrm{m}$ in tangential height; upright cells $28-42 \mu \mathrm{m}$ in radial length and 36$42 \mu \mathrm{m}$ in tangential height (figure $7 \mathrm{~g}$ ). Fibres angular in cross section, moderately thick walled, nonseptate, 22-28 $\mu \mathrm{m}$ in diameter, and $250-330 \mu \mathrm{m}$ in length (figure $7 \mathrm{~b}, \mathrm{~d}$ ). Gum canals normal, vertical, arranged in concentric rings, usually smaller than vessels, t.d. 56-112 $\mu \mathrm{m}$ and r.d. $60-112 \mu \mathrm{m}$ (figure $7 \mathrm{a}, \mathrm{f}$ ).

Figured specimen: Specimen no. BSIP39842.

No. of specimens: 2.

Horizon: Tipam Group.

Locality: Subansiri riverbeds in Dhemaji, Dhemaji

District, Assam.

Age: Middle-Late Miocene.

Remarks: The important diagnostic features of the present fossil wood are: presence of growth rings marked by concentric rings of gum canals enclosed in parenchyma bands, small to large vessels, simple perforation plates, vestured intervessel pits, absence of tyloses in the vessels, mostly vasicentric to aliform-confluent parenchyma, $1-5$ seriate xylem rays, heterogeneous ray tissue and nonseptate fibres. They indicate affinity with xylotomically inseparable taxa Copaifera Linn., Detarium Jussieu and Sindora Miquel of the family Fabaceae (Metcalfe and Chalk 1950; Normand 1950; Kribs 1959; Lalitha and Prakash 1980; Ilic 1991).

Müller-Stoll and Mädel (1967) instituted the genus Copaiferoxylon to include the fossil woods with concentric rows of gum canals resembling Copaifera, Detarium and Sindora. Lemoigne et al (1974) instituted another genus Sindoroxylon for describing the fossil wood resembling Sindora. Boureau and Louvet (1975) erected one more genus Detarioxylon for their fossil wood resembling Detarium. Awasthi (1977) assigned the affinities of Hopeoxylon indicum (Navale 1963b) to Sindora instead of Hopea of the family Dipterocarpaceae. Therefore, Lalitha and Prakash (1980) opined that Hopeoxylon Navale emend. (Awasthi 1977) should get priority over the other names and had adopted it to designate fossil wood of Copaifera, Detarium and Sindora instead of Sindora only as pointed out by Awasthi (1977). Till date nine species of Hopeoxylon are known from various parts of the world. These are: $H$. migiurtinum (Chiarugi) (Lalitha and Prakash 1980) from the Miocene of Somalialand, H. sindoroides (Kramer) (Lalitha and Prakash 1980) from the Tertiary of West Borneo, H. aethiopium (Lemoigne et al) (Lalitha and Prakash 1980) from the Tertiary of Ethiopia, H. libycum (Bureau and Louvet) (Lalitha and Prakash 1980) from the Paleogene of Libya, H. indicum Navale emend. (Awasthi 1977), H. arcotense (Awasthi 1977) and H. speciosum (Navale) (Awasthi 1977) from the Cuddalore Sandstone of south India, H. assamicum (Lalitha and Prakash 1980) from the Late Miocene of Hailakandi, Assam and H. eosiamensis (Prakash 1981) from the Lower Siwalik of Uttar Pradesh. After detailed comparison it has been found that our fossil resembles $H$. assamicum in all the features and therefore, is being described under the same species.

The genus Copaifera is found in tropical America and Africa, while Detarium is confined to tropical Africa only. Sindora comprising about 18-20 species is found in the tropical evergreen forest of southeast Asia, Hainan, western Malaysia, Celebes and Molucca (Ridley 1967; Willis 1973; Mabberley 1997). The distribution pattern of the above three genera indicates that Sindora may be the nearest comparable form of the fossil as the rest of the taxa are found in the continents located very far from the present fossiliferous site.

Genus: Millettioxylon Awasthi (1967)

Millettioxylon pongamiensis Prakash (1975)

(figure 8a-f)

Description: Wood diffuse porous (figure 8a). Growth rings absent. Vessels small to medium, rarely very small, t.d. $60-145 \mu \mathrm{m}$, r.d. $28-140 \mu \mathrm{m}$, solitary and in radial multiples of $2-3$, rarely in tangential pairs or clusters, round to oval, evenly distributed, $7-15$ per $\mathrm{mm}^{2}$, tyloses absent (figure 8a-b); vessel members truncate, storied, 800-1000 $\mu \mathrm{m}$ in height (figure 8e); perforations simple; intervessel pits bordered, alternate, about 4-6 $\mathrm{mm}$ in diameter, circular to oval, vestured (figure 8f). Parenchyma paratracheal banded, bands regular, continuous, alternating with fibre bands, 3-6 cells wide (figure 8a-b); cells 16-42 $\mu \mathrm{m}$ in diameter and $42-112 \mu \mathrm{m}$ in height (figure $8 \mathrm{c}-\mathrm{d}$ ). Xylem rays $8-10$ per $\mathrm{mm}$, mostly biseriate, uniseriates and triseriates rare, storied, made up of procumbent cells only, sometimes showing extensions of $1-6$ cells; uniseriate rays about $22 \mu \mathrm{m}$ in width and $4-5$ cells or $18-20 \mu \mathrm{m}$ in height; multiseriate rays $33-50 \mu \mathrm{m}$ in width and $7-17$ cells or $275-550 \mu \mathrm{m}$ in height (figure 8c-d); end to end ray fusion rare; ray tissue homogeneous (figure 8e); ray cells crystalliferous, $60-110 \mu \mathrm{m}$ in radial length and 14-56 $\mathrm{m}$ in tangential height (figure 8e). Fibres angular in cross section, thick to moderately thick walled, nonseptate, $8-28 \mu \mathrm{m}$ in diameter and about 224-280 $\mu \mathrm{m}$ in length (figure 8b, d). Ripple marks present due to storied nature of xylem rays and vessel elements. 

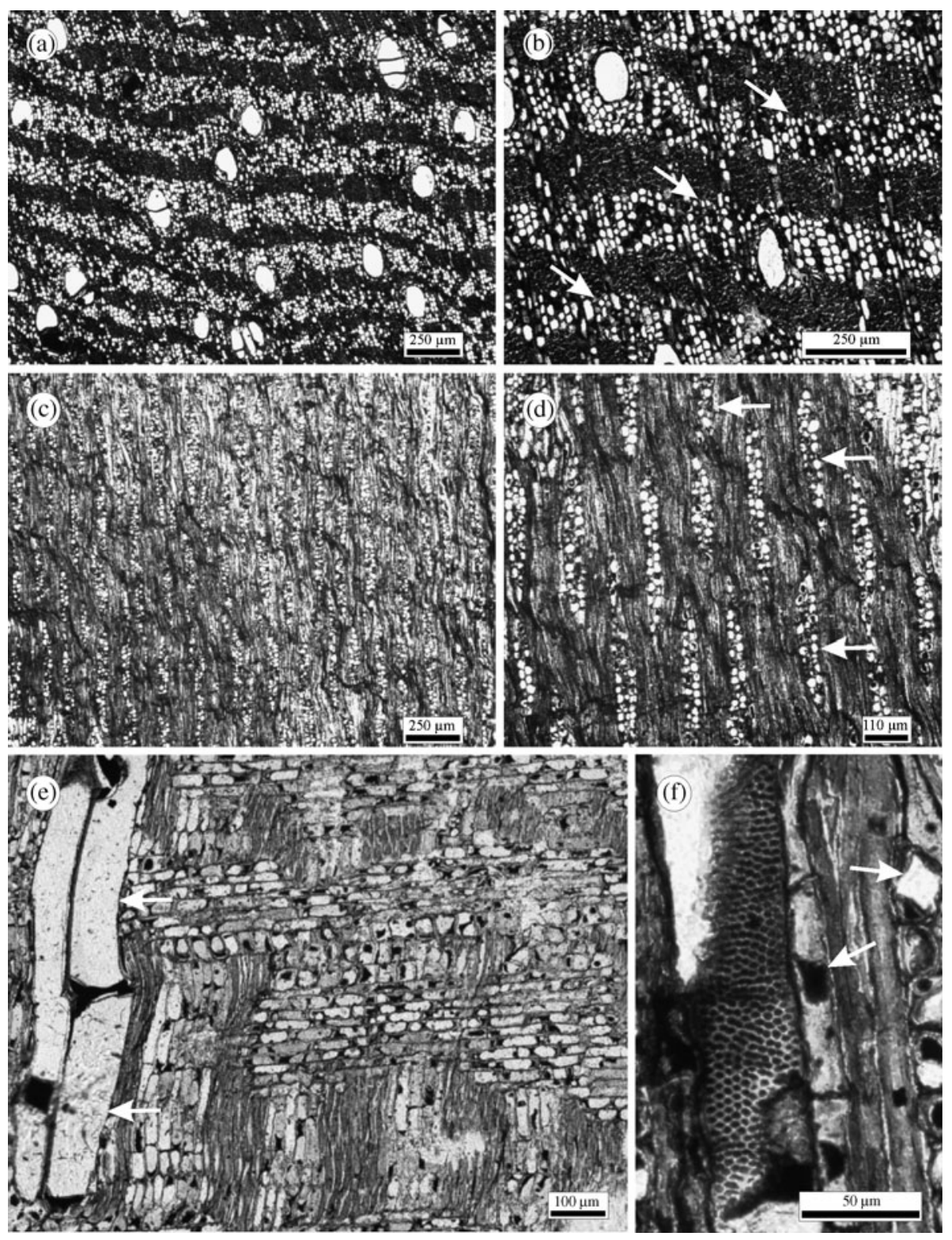

Figure 8. Millettioxylon pongamiensis Prakash, (a) showing shape, size and distribution of vessels, (b) showing parenchyma bands (marked by arrows) alternating with thicker fibre bands, (c) showing structure of xylem rays, (d) showing storied nature of xylem rays (marked by arrows), (e) showing homogeneous ray tissue and storied vessel elements (marked by arrows), and (f) vestured intervessel pits and crystals in ray cells (marked by arrows).

Figured specimen: Specimen no. BSIP39843.

No. of specimens: 11.

Horizon: Tipam Group.

Locality: Subansiri riverbeds in Dhemaji, Dhemaji

District, Assam.

Age: Middle-Late Miocene.

Remarks: The diagnostic features of the fossil wood, viz., diffuse-porous wood, presence of ripple marks due to storied nature of xylem rays and vessel elements, simple perforation plates, vestured intervessel pits, moderately broad continuous bands of parenchyma alternating with fibre bands, mostly biseriate homocellular xylem rays, nonseptate fibres and open vessels indicate affinities with the modern wood of Millettia W. and A. and Pongamia Vent. of the Fabaceae (Pearson and Brown 1932; Metcalfe and Chalk 1950; Kribs 1959; Ramesh Rao et al 1972; Ilic 1991). Prakash (1975) has made a detailed anatomical study of the wood of Millettia and Pongamia, along with some other similar taxa, such as Bauhinia Linn., Craibia Harms and Dunn., Cynometra Linn., Dialium Linn., Lonchocarpus Kunth. and Swartzia Schreb. and found that their wood can be classified into the following three groups:

- 1st Group: made up of some species of Millettia and Pongamia glabra Vent.

- 2nd Group: consisting of only Millettia spp. 
- 3rd Group: includes wood of Millettia, Craibia, Dialium and Swartzia.

Our fossil having broad bands, less than 4 seriate homocellular xylem rays and storied elements can be classified under 1st Group having xylotomically indistinguishable $M$. prainii Dunn., M. pendula Benth. and P. glabra Vent. Though Awasthi (1967) instituted the genus Millettioxylon for the fossil wood resembling Millettia pendula from the Cuddalore Sandstone Formation of south India, Prakash (1975) on the basis of the above-mentioned facts suggested that fossil wood belonging to the 1st Group should be assigned to Millettioxylon Awasthi. The 2nd Group having broader (more than 4 seriate) xylem rays was suggested the name Eumillettioxylon, while the 3rd Group characterized by narrower parenchyma bands and xylem rays was designated as Dialiumoxylon. Unfortunately, he did not propose any generic diagnosis for Eumillettioxylon and Dialiumoxylon.

The genus Millettioxylon (Awasthi 1967) to which the present fossil belongs, consists of the following six species: M. indicum (Awasthi 1967) from the Cuddalore Sandstone Formation of south India, M. pongamiensis (Prakash 1975) from the Lower Siwalik of Himachal Pradesh, M. bengalensis (Ghosh and Roy 1979) from the Tertiary sediments of Midnapur District of West Bengal, $M$. palaeopulchra (Lakhanpal et al 1981) from the Namsang beds of Deomali, Arunachal Pradesh, M. kalagarhensis (Trivedi and Mishra) (Guleria 1984a) and $M$. embergeri (Lemoigne 1978) from the Tertiary of Ethiopia. After detailed comparison it has been found that our fossil is similar to $M$. pongamiensis Prakash in all the features and therefore, has been kept under the same species.

Millettia is a genus of about 90 species of trees, shrubs and woody climbers found in the warmer regions of Africa, Asia and Australia. About 30 of its species are reported to occur in the Indian subcontinent, especially in Myanmar. M. prainii is a small-sized tree found in the eastern Himalayas in the foot hills of Sikkim extending into the plains of north Bengal, Assam and Meghalaya. M. pendula is a medium-sized tree distributed in the drier forests of Myanmar, Pegu Yoma, Shweba, Upper Chindwin and Tenasserim, while Pongamia glabra is also a medium-sized tree found throughout the greater part of India and Myanmar, chiefly along streams and rivers, being common in the tidal and beach forests. It is also found in Sri Lanka and Malaysia extending to north Australia and China.

Genus: Pahudioxylon Chowdhury et al (1960) Pahudioxylon deomaliense Prakash (1966)

(figure $9 \mathrm{a}-\mathrm{g}$ )
Description: Wood diffuse porous (figure 9a). Growth rings present, marked by terminal parenchyma (figure 9a). Vessels small to large but mostly medium, t.d. $120-190 \mu \mathrm{m}$, r.d. $75^{-}$ $230 \mu \mathrm{m}$, solitary as well as in radial multiples of $2-$ 4 , round to oval, evenly distributed, $4-6$ per $\mathrm{mm}^{2}$, tyloses occasionally present (figure $9 \mathrm{a}-\mathrm{b}$ ); vessel members truncate, storied, $180-400 \mu \mathrm{m}$ in height (figure 9f); perforations simple; intervessel pits bordered, alternate, $5-11 \mu \mathrm{m}$ in diameter, circular to oval (but appearing hexagonal due to crowding), vestured (figure 9d). Parenchyma both paratracheal and apotracheal; paratracheal typically aliform forming 8-14 celled thick sheath around the vessels, occasionally confluent joining similar extensions from adjacent vessels; apotracheal terminal, 2-4 cells or 31-56 $\mu \mathrm{m}$ in thickness (figure $9 \mathrm{a}-\mathrm{b}$ ); cells storied, $17-47 \mu \mathrm{m}$ in diameter and 35-115 $\mu \mathrm{m}$ in height (figure $9 \mathrm{~g}$ ). Xylem rays $11-14$ per $\mathrm{mm}, 1-4$ seriate, mostly $2-3$ seriate, homocellular made up of procumbent cells only, showing tendency towards storied arrangement; uniseriate rays $11-12 \mu \mathrm{m}$ in width and 120 $204 \mu \mathrm{m}$ in height; multiseriate rays $18-54 \mu \mathrm{m}$ in width and 9-20 cells or 210-440 $\mu \mathrm{m}$ in height (figure 9c, e); ray tissue homogeneous (figure 9f-g); ray cells $31-82 \mu \mathrm{m}$ in radial length and $12-24 \mu \mathrm{m}$ in tangential height (figure $9 \mathrm{f}-\mathrm{g}$ ). Fibres angular in cross section, thick walled, nonseptate, crystalliferous, $7-14 \mu \mathrm{m}$ in diameter and about $500 \mu \mathrm{m}$ in length (figure 9b, e).

Figured specimen: Specimen no. BSIP39844.

No. of specimens: 1 .

Horizon: Tipam Group.

Locality: Dirpai riverbeds in North Lakhimpur, Lakhimpur District, Assam.

Age: Middle-Late Miocene.

Remarks: The characteristic features of the fossil are: diffuse porous wood, occurrence of growth rings delimited by terminal parenchyma, storied vessel elements, typically aliform to aliformconfluent parenchyma, simple perforation plates, vestured intervessel pits, 1-4 seriate homocellular xylem rays having storied tendency and nonseptate fibres. These characters collectively indicate affinity with the xylotomically indistinguishable taxa Afzelia Smith and Intsia Thouin of the Fabaceae (Pearson and Brown 1932; Metcalfe and Chalk 1950; Kribs 1959; Ramesh Rao et al 1972; Ilic 1991).

Chowdhury et al (1960) instituted the genus Pahudioxylon for the fossil wood showing affinities with that of Pahudia Miq. They were unaware of the fact that Pahudia had already been merged with Afzelia by Leonard (1950). Therefore, Prakash (1966) redefined the organ genus to 

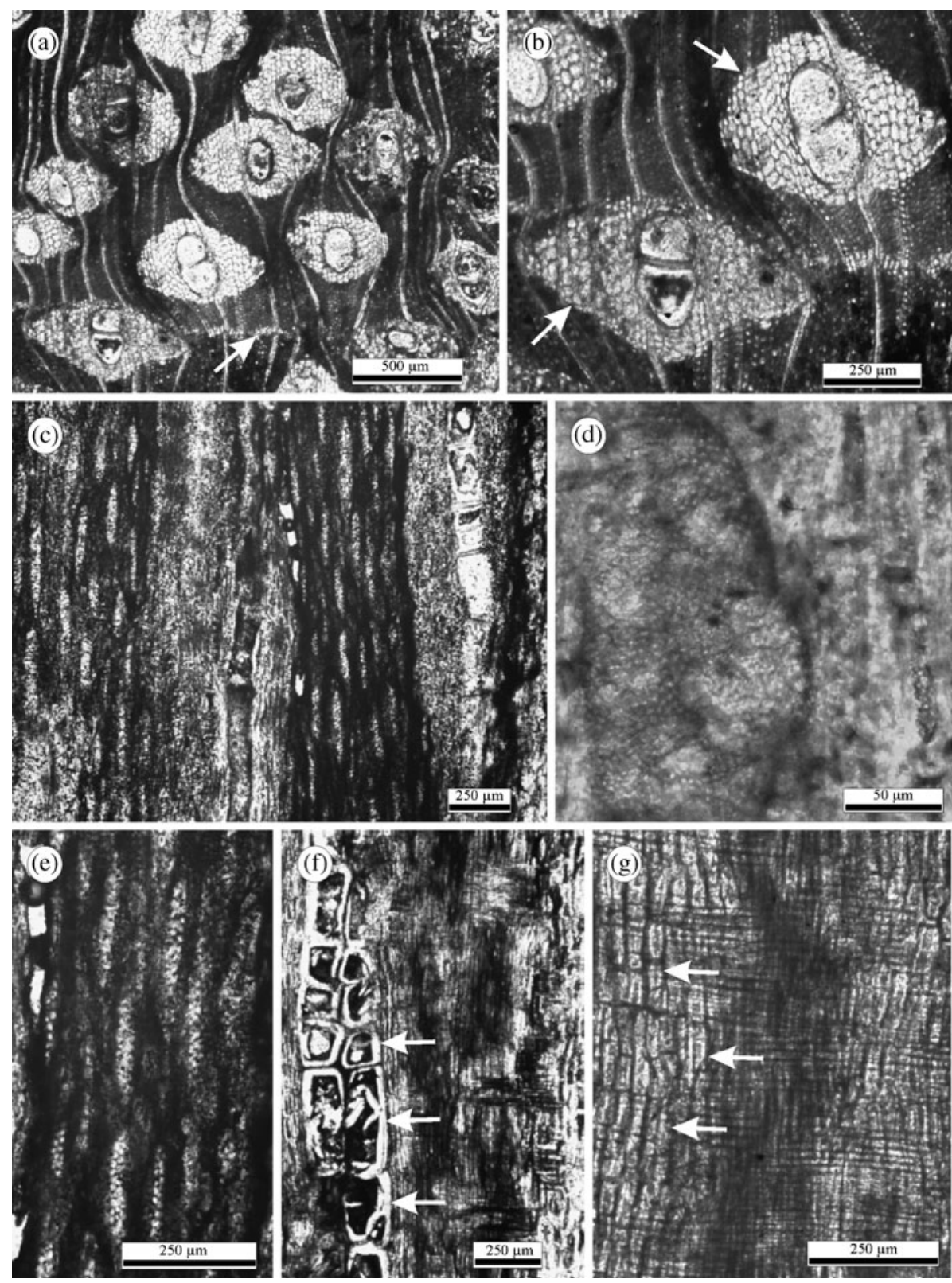

Figure 9. Pahudioxylon deomaliense Prakash, (a) showing shape, size and distribution of vessels and terminal parenchyma (marked by arrows), (b) showing typical aliform parenchyma (marked by arrows), (c) showing distribution of xylem rays, (d) vestured intervessel pits, (e) showing structure of xylem rays, (f) showing storied vessel elements (marked by arrows), and $(\mathrm{g})$ showing homogeneous ray tissue and storied parenchyma cells (marked by arrows).

include fossil wood of Afzelia-Intsia also. So far the following 16 species of it are known from various Tertiary exposures of the world: P. bankurensis (Chowdhury et al 1960) from West Bengal, P. sahnii (Ghosh and Kazmi 1961) from Tripura, $P$. arcotense (Navale 1963a) from Pondicherry, P. deomaliense (Prakash 1966) from Arunachal Pradesh, P. assamicum (Prakash and Tripathi 1975) from Assam, P. indicum (Prakash 1979b) from Himachal Pradesh, P. bengalensis (Ghosh and Roy 1982) from West Bengal, P. garbetaense (Bera and Banerjee 2001) from West Bengal (all from India), $P$. afzelioides (Boureau) and $P$. kiliani (Louvet) from Indo-China and Algeria respectively (Prakash et al 1967), P. irregulare and $P$. pannonicum from Antigua and Hungary respectively (Müller-Stoll and Mädel 1967), P. welkitii Lemoigne from Ethiopia, P. paracochinchinense (Vozenin-Serra 1981) from South Vietnam and $P$. furoni (Koeniguer) (Guleria 1984a) and $P$. aethiopcum (Lemoigne et al) (Guleria 1984a) from Republic of Chad and Ethiopia, respectively. Unfortunately, most of these species were established on the basis of minor variations and could be restricted to a few species. Therefore, instead of creating a new species based on minor variations, 
we have placed our fossil under $P$. deomaliense (Prakash 1966) with which it shares maximum resemblance.

Afzelia is a genus of medium to large-sized trees consisting of 12 species found in tropical Africa and Asia, while Intsia has three species found in offshore islands of tropical East Africa, Madagascar and tropical Asia (Willis 1973; Mabberley 1997). In India Intsia occurs near mangroves in Sunderbans and Andamans.

\section{Discussion}

For the reconstruction of palaeoclimate many parameters are in practice, viz., Nearest Living Relative Approach (NLR) (Prakash et al 1994; Estrada-Ruiz et al 2007; Jeong et al 2009; Feng et al 2010), Leaf Margin Analysis (LMA) (Wilf 1997; Su et al 2010), Climate Leaf Analysis Multivariate Program (CLAMP) (Wolfe 1993; Spicer et al 2009) and Coexistence Approach (CoA) (Mosbrugger and Utescher 1997; Böhme et al 2007). However, for the analysis of fossil wood the best and reliable method is NLR as it is considered that very little or insignificant change has taken place in wood characters in relation to climate. In the above technique, the plant fossils are considered to be the reliable indicator of the past climate. The modern equivalents of the present fossil assemblage are: Gluta (Anacardiaceae), Bischofia javanica (Euphorbiaceae), Bauhinia malabarica, Cynometra polyandra, C. ramiflora, CopaiferaDetarium-Sindora, Millettia pendule, M. prainii, Pongamia glabra and Afzelia-Intsia (Fabaceae). The distribution pattern of these taxa presented in the form of a table (table 2) clearly indicates a tropical climate.

Xylotomical characters have also been used to predict climate by various workers (Wheeler and Baas 1993; Martínez-Cabrera and Cevallos-Ferriz 2008). According to Wheeler and Baas (1991, 1993) diameter and density of vessels can be used to infer presence of tropical or temperate conditions. In wood of little seasonality, vessels may be evenly distributed and of approximately uniform size throughout the wood (diffuse porous condition); while in wood of climates of marked seasonality, vessels may be larger and more numerous in early wood and fewer and smaller in late wood (ring porous condition). As all the fossil wood logs in the present assemblage are diffuse porous in nature and none of them shows ring porosity, they support tropical conditions with little seasonality. The tropical forests of India which have been classified into seven types by Champion and Seth (1968) are: wet evergreen, semi-evergreen, moist deciduous, dry deciduous, littoral and swampy, thorny

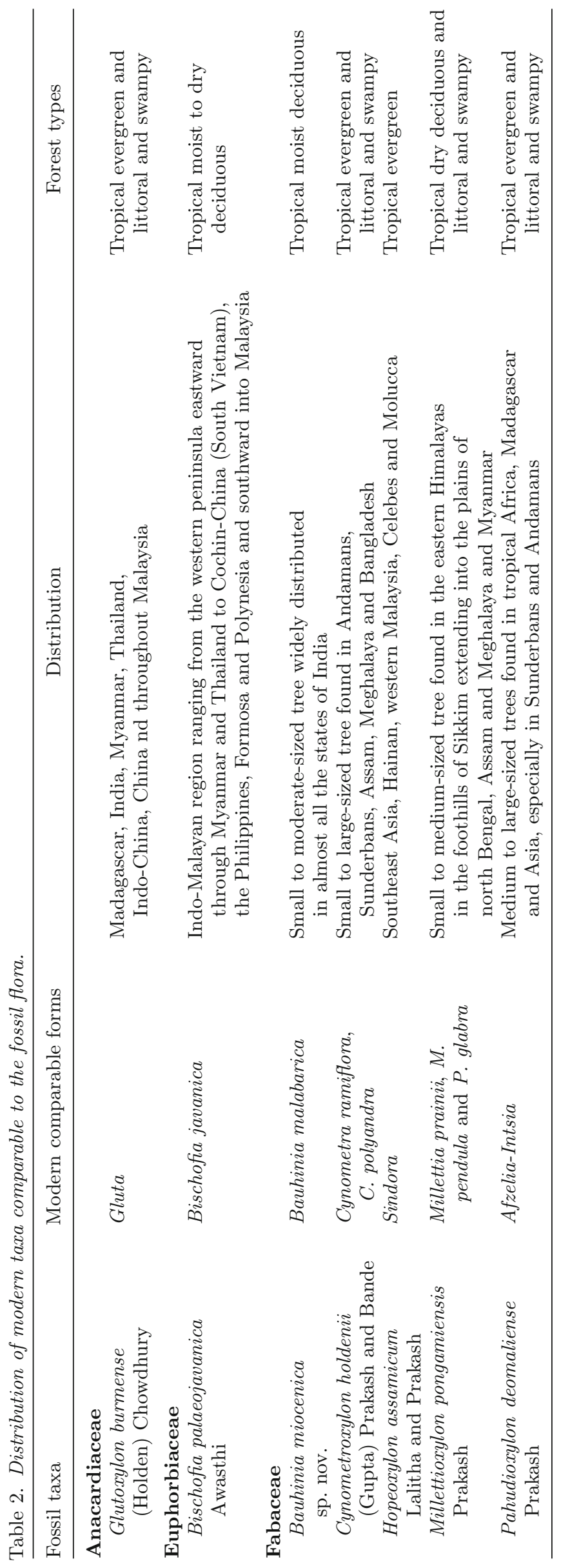


deciduous and dry evergreen. As per the table (table 2) Gluta, Bauhinia malabarica, Cynometra polyandra, C. ramiflora, Sindora, Millettia prainii, Pongamia glabra and Afzelia-Intsia are growing at present in the tropical evergreen to moist deciduous and littoral and swampy forest. Bischofia javanica shows its range from moist deciduous to dry deciduous forest, while Millettia pendule is found only in dry deciduous forest. As majority of the taxa occur in tropical evergreen to moist deciduous and littoral and swampy forest, it can be inferred from the above facts that a warm and humid climate was prevalent in Upper Assam during the MiddleLate Miocene. The occurrence of Gluta, AfzeliaIntsia and Cynometra ramiflora indicates coastal conditions in the region. It means that the sea was situated much more inland than where it is today. This might have some impact over the vegetation of the region. Lakhanpal (1970) has already suggested that the Bay of Bengal was extending northwards than its present day boundary. According to Wolfe and Upchurch Jr (1987) woody plants growing in periods of drought show grouping of vessels, reduction in vessel diameter, increase in vessel density and development of vasicentric tracheids, while those growing in abundant precipitation have high proportions of large and solitary vessels with simple perforation plates and lack vasicentric tracheids. In the present assemblage vasicentric tracheids are absent and vessels are generally large with simple perforation plates which indicate high precipitation. It has been further observed by Wolfe and Upchurch Jr (1987) that mega thermal woods have high amount of paratracheal parenchyma. As most of the taxa in the present assemblage have this type of parenchyma, this indicates high temperature. The presence of homocellular and storied rays in some of the taxa of the assemblage supports the above view (Woodcock and Ignas 1994). The present fossil assemblage has also been compared with the palynological as well as megafossil data obtained from the nearby areas of Assam (Prakash et al 1994; Kumar et al 2001; Mehrotra et al 2005) and it is found that our interpretations are in line with them.

The coexistance analysis (CoA) developed by Mosbrugger and Utescher (1997) is based on the concept that the climatic requirements of fossil species are similar to those of their NLRs (Mosbrugger 1999). It reconstructs the paleoclimate parameters for a given fossil flora using climatic intervals in which all the NLRs of the fossil flora could coexist. The climatic tolerances of all the fossil wood NLRs of the present assemblage (table 2) are obtained from Champion and Seth (1968) and climatological tables of observatories in India (1931-1960) and the following reconstructed climatic estimates are obtained: MAT (mean annual temperature) $23.1-26^{\circ} \mathrm{C}, \mathrm{CMT}$ (mean temperature of the coldest month) 20 $21^{\circ} \mathrm{C}$, WMT (mean temperature of the warmest month) $25-27.1^{\circ} \mathrm{C}$, MAP (mean annual precipitation) 2160-2625 mm (figure 10a-d) and $\mathrm{RH}$ (mean relative humidity) $77.5 \%$. It is observed that maximum NLRs could coexist in the obtained climate ranges though Sindora and B. malabarica are two outliers which indicate anomalous evolutionary changes. Exclusion of these outliers minimizes the effect of such changes. The data obtained (figure 10) shows that the seasonality was less pronounced at the time of deposition which supports the existence of tropical climate as deduced from the modern comparable forms of the fossil taxa (table 2). The result obtained supports the above view of warm and humid conditions in the region.

The fossil assemblage is conspicuous in having some southeast Asian elements, such as Gluta, Afzelia-Intsia and Sindora. The theory of Plate Tectonics helps in explaining their presence in the flora. According to Smith and Briden (1979), Smith et al (1994) and Chatterjee and Scotese (1999) the Indian Plate was moving northwards after its separation from the other Gondwanaland continents during the Cretaceous. At the end of the Eocene it collided with the Asian Plate, but suturing between them was not complete in order to facilitate the migration of taxa. The land connections were established by the end of the Late Oligocene/Early Miocene as Dipterocarpaceae, the typical Malaysian element, was absent in India during the Palaeogene. As most of the southeast Asian elements entered India through its northeast corner (Assam) during the Middle Miocene (Srivastava and Mehrotra 2010), we get Gluta, Afzelia-Intsia and Sindora in the fossil assemblage. These taxa were growing luxuriantly during the Neogene not only in northeast India but also in eastern, western, southeastern and northern parts of India (Awasthi 1992; Guleria 1992). After the Neogene, they disappeared from the Indian subcontinent due to the decrease in temperature caused by further uplift of the Himalaya due to the sinking of the Indian Plate against the Asian Plate. Being sensitive to the changing environment they failed to survive. Gluta travancorica Bedd. is the only living species which occurs in the extreme south of India under the equable climate (Champion and Seth 1968).

In the present assemblage the fabaceous genera are more in comparison to those of the other families. The same has also been observed by Antal and Awasthi (1993) and Prasad et al (2004) while describing their fossil assemblage from the MiddleLate Miocene of India and Nepal, respectively. The 

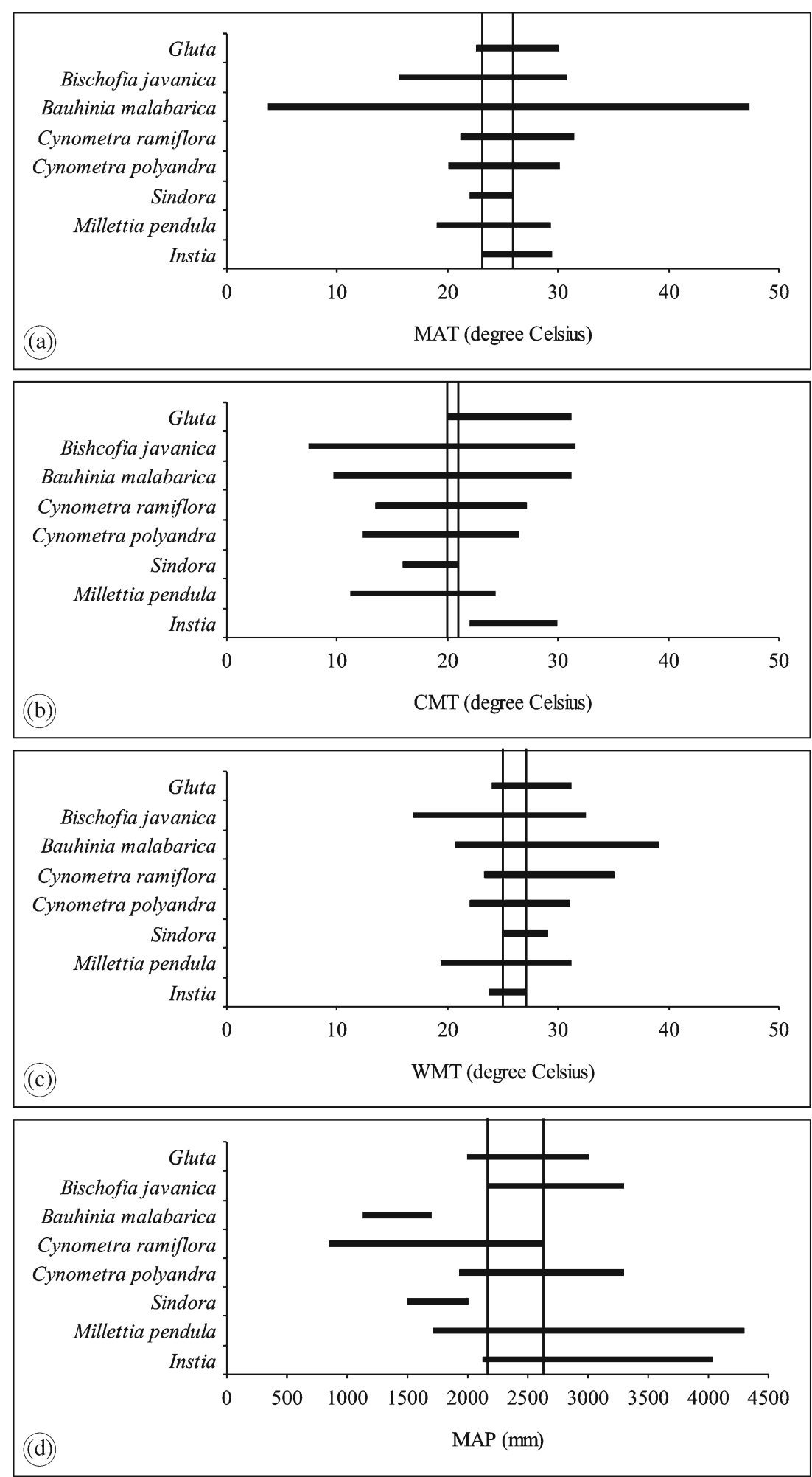

Figure 10. The coexistence interval of the climatic parameters of the megafossils showing, (a) MAT, (b) CMT, (c) WMT, and (d) MAP (vertical lines indicating common range of all the modern comparable forms).

following two reasons may be attributed for the same:

- A global warming has been observed at the end of the Oligocene and continued up to the
Middle Miocene. This warm phase peaked in the late Middle Miocene climatic optimum (Zachos et al 2001). Punyasena et al (2008) have suggested that the abundance and richness of the family Fabaceae covary with the temperature. 
Therefore, $70 \%$ of the taxa in the present assemblage belong to the above family. As during the Middle Miocene the temperature was high, the family flourished a lot.

- During the Middle Miocene a lot of plant migration occurred in India from the neighbouring landmasses (Mehrotra et al 2005). As a result many taxa of the Fabaceae growing in southeast Asia migrated and flourished in India under the equable climate.

\section{Conclusion}

A good number of fossil wood pieces have been collected from two new localities situated in the north Lakhimpur and Dhemaji Districts of Assam. They belong to the Tipam Group considered to be Middle-Late Miocene in age and are of seven types, namely Glutoxylon burmense, Bischofia palaeojavanica, Bauhinia miocenica, Cynometroxylon holdenii, Hopeoxylon assamicum, Millettioxylon pongamiensis and Pahudioxylon deomaliense of which $B$. miocenica is a new species. The distribution pattern of their modern equivalents clearly indicates the prevalence of tropical climate in the region during the depositional period. As majority of the taxa occur in tropical evergreen to moist deciduous and littoral and swampy forest, a warm and humid climate may be envisaged in Upper Assam during the Middle-Late Miocene. As most of the taxa possess diffuse porous wood, paratracheal parenchyma, simple perforation plates, large vessels and storied elements, they support the above inference. The presence of some southeast Asian elements in the fossil assemblage provides clear evidence of the complete suturing between Indian and Asian plates in order to facilitate migration of taxa.

\section{Acknowledgements}

The authors are thankful to the Director, Dr N C Mehrotra, of the Birbal Sahni Institute of Palaeobotany, Lucknow for providing the basic facilities and permission to carry out this work. They are also grateful to the anonymous reviewers for their critical comments and helpful suggestions for improving the manuscript.

\section{References}

Agarwal A 1994 A fossil wood of Bischofia from Neyveli lignite deposits, India; J. Indian Bot. Soc. 73 335-336.

Antal J S and Awasthi N 1993 Fossil flora from the Himalayan foot-hills of Darjeeling District, West Bengal and its palaeoecological and phytogeographical significance; Palaeobotanist 42 14-60.
Awasthi N 1966 Fossil woods of Anacardiaceae from the Tertiary of south India; Palaeobotanist 14 131-143.

Awasthi N 1967 Fossil wood resembling that of Millettia from the Tertiary of south India; Curr. Sci. 36 180181.

Awasthi N 1977 Revision of Hopeoxylon indicum Navale from the Cuddalore Series near Pondicherry; Palaeobotanist 24 102-107.

Awasthi N 1989 Occurrence of Bischofia and Antiaris in Namsang beds (Miocene-Pliocene) near Deomali, Arunachal Pradesh, with remarks on the identification of fossil woods referred to Bischofia; Palaeobotanist $\mathbf{3 7}$ $147-151$.

Awasthi N 1992 Changing patterns of vegetation through Siwalik succession; Palaeobotanist 40 312-327.

Awasthi N and Mehrotra R C 1990 Some fossil woods from Tipam Sandstone of Assam and Nagaland; Palaeobotanist 38 277-284.

Awasthi N and Mehrotra R C 1997 Some fossil dicotyledonous woods from the Neogene of Arunachal Pradesh, India; Palaeontographica B 245 109-121.

Awasthi N and Prakash U 1987 Fossil woods of Kingiodendron and Bauhinia from the Namsang beds of Deomali, Arunachal Pradesh; Palaeobotanist 35 178-183.

Bande M B 1974 Two fossil woods from the Deccan Intertrappean beds of Mandla District, Madhya Pradesh; Geophytology 4 189-195.

Bande M B, Dechamps R, Lakhanpal R N and Prakash U 1987 Some new fossil woods from the Cenozoic of Zaire; Mus. Roy. Afr. Centr., Tervuren (Belg.), Dépt. Géol. Min., Rapp. Ann. 1985-1986, pp. 113-140.

Bera S and Banerjee M 2001 Petrified wood remains from Neogene sediments of the Bengal basin, India, with remarks on palaeoecology; Palaeontographica B 260 167-199.

Böhme M, Bruch A A and Selmeier A 2007 The reconstruction of Early and Middle Miocene climate and vegetation in southern Germany as determined from the fossil wood flora; Palaeogeogr. Palaeoclimatol. Palaeoecol. 253 91-114.

Boureau E and Louvet P 1975 Sur deux especes ligneuses tertiaries nouvelles de la région de ouaou en namous (Libye); 95e Congr. Nat. Soc. Savantes, Reims Sci. 3 $11-42$.

Champion H G and Seth S K 1968 The Forest Types of India, Manager of Publications, Delhi.

Chatterjee S and Scotese C R 1999 The breakup of Gondwana and the evolution and biogeography of the Indian plate; Proc. Indian Nat. Sci. Acad. A 65 397-425.

Chowdhury K A 1934 A fossil dicotyledonous wood from Assam; Curr. Sci. 3 255-256.

Chowdhury K A 1936 A fossil dicotyledonous wood from Assam; Ann. Botany London 50 501-510.

Chowdhury K A 1952 Some more fossil woods of Glutoxylon from south-east Asia; Ann. Botany N. S. 16 373-378.

Chowdhury K A and Ghosh S S 1946 On the anatomy of Cynometroxylon indicum gen. et sp. nov. - a fossil dicotyledonous wood from Nailalung, Assam; Proc. Nat. Inst. Sci. India 12 435-447.

Chowdhury K A, Ghosh S S and Kazmi M H 1960 Pahudioxylon bankurensis gen. et sp. nov. - a fossil dicotyledonous wood from the Miocene beds of Bankura District, West Bengal; Proc. Nat. Inst. Sci. India $\mathbf{2 6}$ $22-28$.

Climatological Tables of Observatories in India (1931-1960) India Meteorological Department, Government of India Press, Nasik.

Estrada-Ruiz E, Martinez-Cabrera H I and Cevallos-Ferriz R S 2007 Fossil woods from the late Campanion-early 
Maastrichtian Olmos Formation Coahuila, Mexico; Rev. Palaeobot. Palynol. 145 123-133.

Feng X X, Yi T M and Jin J H 2010 First record of Paraphyllanthoxylon from China; IAWA Journal 31 89-94.

Ghosh P K and Roy S K 1979 A new species of Millettia from the Tertiary of West Bengal, India; Curr. Sci. 48 $165-166$.

Ghosh P K and Roy S K 1982 Fossil woods of Caesalpinioidae from the Miocene of West Bengal; Acta Botanica Indica 10 50-55.

Ghosh S S and Kazmi M H 1961 Pahudioxylon sahnii sp. nov., a new fossil record from the Miocene (?) of Tripura; Sci. Cult. 27 96-98.

Ghosh S S and Purkayastha S K 1963 Family Anacardiaceae, In: Indian Woods (eds) Ghosh et al, Manager of Publications, Delhi 2 264-323.

Guleria J S 1984a Leguminous woods from the Tertiary of District Kachchh, Gujarat, western India; Palaeobotanist $31238-254$.

Guleria J S 1984b Occurrence of anacardiaceous woods in the Tertiary of western India; Palaeobotanist 32 35-43.

Guleria J S 1992 Neogene vegetation of peninsular India; Palaeobotanist 40 285-311.

Guleria J S, Gupta S S and Srivastava R 2002 Fossil woods from Upper Tertiary sediments of Jammu region (Jammu and Kashmir) north-west India and their significance; Palaeobotanist 50 225-246.

Guleria J S and Srivastava R 2001 Fossil dicotyledonous woods from the Deccan Intertrappean beds of Kachchh, Gujarat, western India; Palaeontographica B 257 $17-33$.

Gupta S 2007 Atlas of Indian Hardwoods: Their Photomicrographs and Anatomical Features, Vol. 1, Forest Research Institute, Dehradun.

Hou D 1978 Florae Malesianae praecursores LVI. Anacardiaceae; Blumea 24 1-41.

IAWA Committee 1989 IAWA list of microscopic features for hardwood identification; IAWA N. S. 10 219-332.

Ilic J 1991 CSIRO Atlas of Hard Woods, Springer-Verlag, Berlin.

Jeong E K, Kim K, Suzuki M and Kim J W 2009 Fossil woods from the Lower coal-bearing Formation of the Janggi Group (Early Miocene) in the Pohang Basin, Korea; Rev. Palaeobot. Palynol. 153 124-138.

Karunakaran C 1974 Geology and mineral resources of the states of India. Part IV - Arunachal Pradesh, Assam, Manipur, Meghalaya, Mizoram, Nagaland and Tripura; Geol. Surv. India Misc. Publ. No. 30 1-124.

Kribs D A 1959 Commercial foreign woods on the American market, Pennsylvania State University, Pennsylvania.

Kumar M, Mandal J P, Dutta S K, Bhuyan D, Das B and Saikia B 2001 Palynostratigraphy of the subsurface sediments of Upper Assam basin, India; Geobios 34 $241-251$.

Lakhanpal R N 1970 Tertiary flora of India and their bearing on the historical geology of the region; Taxon 19 675-694.

Lakhanpal R N, Prakash U and Awasthi N 1981 Some more dicotyledonous woods from the Tertiary of Deomali, Arunachal Pradesh, India; Palaeobotanist 27 232-252.

Lalitha C and Prakash U 1980 Fossil wood of Sindora from the Tertiary of Assam with a critical analysis of anatomically allied forms; Geophytology 10 174-187.

Lemoigne Y 1978 Flores Tertiares de la Haute Vallee de L'omo (Ethiopie); Palaeontographica B 165 89-157.

Lemoigne Y, Beauchamp J and Samuel E 1974 Étude palaeobotanique dés depots volcaniques d'age Tertiare des bordures est et ouest du systeme des rifts Éthiopiens; Geobios 7 267-288.
Leonard J J G 1950 Notes sur les, genres palaetropicans, Afzelia, Intsia et Pahudia (Leguminosae-Caesalpiniae); Reinwardtia 1 61-66.

Mabberley D J 1997 The plant book. A portable dictionary of vascular plants, Cambridge University Press, Cambridge.

Mädel E 1962 Die fossilen Euphorbiaceen-hölzer mit besonderer Berücksichtigung neuer Funde aus der Oberkreide Süd-Africas; Senck. Leth. 43 293-321.

Martínez-Cabrera H I and Cevallos-Ferriz S R S 2008 Palaeoecology of the Miocene El Cien Formation (Mexico) as determined from wood anatomical characters; Rev. Palaeobot. Palynol. 150 154-167.

Mehrotra R C, Awasthi N and Dutta S K 1999 Study of fossil wood from the upper Tertiary sediments (Siwalik) of Arunachal Pradesh, India and its implication in palaeoecological and phytogeographical interpretations; Rev. Palaeobot. Palynol. 107 223-247.

Mehrotra R C, Bhattacharyya A and Shah S K 2006 Petrified Neogene woods of Tripura; Palaeobotanist $\mathbf{5 5}$ $67-76$.

Mehrotra R C, Liu Xiu-Qun, Li Cheng-Sen, Wang Yu-Fei and Chauhan M S 2005 Comparison of the Tertiary flora of southwest China and northeast India and its significance in the antiquity of the modern Himalayan flora; Rev. Palaeobot. Palynol. 135 145-163.

Metcalfe C R and Chalk L 1950 Anatomy of the dicotyledons; Vol. 1 and 2, Clarendon Press, Oxford.

Miles A 1978 Photomicrographs of world woods, Building Research Establishment Report, London.

Mosbrugger V 1999 The nearest living relative method, In: Fossil Plants and Spores Modern Techniques (eds) Jones T P and Rowe N P, The Geological Society, London, pp. 261-265.

Mosbrugger V and Utescher T 1997 The coexistance approach - a method for quantitative reconstructions of Tertiary terrestrial palaeoclimatic data using plant fossils; Palaeogeogr. Palaeoclimatol. Palaeoecol. 134 61-86.

Müller-Stoll W R and Mädel E 1967 Die fossilen Leguminosen hölzer, revision der mit Leguminosen verglichenen fossilen hölzer und beschreibungen älterer und neurer Arten; Palaeontographica B 119 95-174.

Navale G K B 1963a Fossil woods of Leguminosae from Tertiary rocks of the Cuddalore Series near Pondicherry, India; Palaeobotanist 11 54-65.

Navale G K B 1963b Some silicified dipterocarpaceous woods from Tertiary beds of the Cuddalore Series near Pondicherry, India; Palaeobotanist 11 66-81.

Normand D 1950 Atlas de Bois de la Cote d'Ivoire. Vol. 1, Centre Technique for Tropical Forestier, Nogent-surMarne.

Pearson R S and Brown H P 1932 Commercial Timbers of India; Vol. 1 and 2, Government of India Central Publication Branch, Calcutta.

Prakash U 1966 Pahudioxylon deomaliense sp. nov., a new fossil wood from the Tertiary of eastern India; Curr. Sci. 34 433-434.

Prakash U 1975 Fossil woods from the Lower Siwalik beds of Himachal Pradesh, India; Palaeobotanist 22192 210.

Prakash U 1979a Fossil dicotyledonous woods from the Tertiary of Thailand; Palaeobotanist 26 50-62.

Prakash U 1979b Some more fossil woods from the Lower Siwalik beds of Himachal Pradesh, India; Himalayan Geol. 8 61-81.

Prakash U 1981 Further occurrence of fossil wood from the Lower Siwalik beds of Uttar Pradesh, India; Palaeobotanist 28-29 374-388.

Prakash U and Bande M B 1980 Some more fossil woods from the Tertiary of Burma; Palaeobotanist 26 261-278. 
Prakash U, Boureau E and Louvet P 1967 Les plans ligneux convergents et la nomenclature de bois de Legumineuses Tertiaires du Sahara et d'Asie; Taxon 16 505-509.

Prakash U and Prasad M 1984 Wood of Bauhinia from the Siwalik beds of Uttar Pradesh, India; Palaeobotanist 32 140-145.

Prakash U and Tripathi P P 1969 On Glutoxylon burmense from Hailakandi in Assam, with critical remarks on the fossil woods of Glutoxylon Chowdhury; Palaeobotanist 17 59-64.

Prakash U and Tripathi P P 1975 Fossil dicotyledonous woods from the Tertiary of eastern India; Palaeobotanist 22 51-62.

Prakash U and Tripathi P P 1976 Fossil dicot woods from the Tertiary of Assam; Palaeobotanist 23 82-88.

Prakash U, Vaidyanathan L and Tripathi P P 1994 Plant remains from the Tipam sandstones of northeast India with remarks on the palaeoecology of the region during the Miocene; Palaeontographica B 231 113-146.

Prasad M, Ghosh R and Tripathi P P 2004 Floristics and climate during siwalik (Middle Miocene) near Kathgodam in the Himalayan foot-hills of Uttranchal, India; J. Palaeontol. Soc. India 49 35-93.

Punyasena S W, Eshel G and McElwain J C 2008 The influence of climate on the spatial patterning of neotropical plant families; J. Biogeogr. 35 117-130.

Ramanujam C G K 1960 Silicified woods from the Tertiary of South India; Palaeontographica B 106 99-140.

Ramanujam C G K and Rao M R R 1966 A fossil wood resembling Bauhinia from the Cuddalore Series of south India; Curr. Sci. 35 375-377.

Ramesh Rao K, Purkayastha S K, Shahi R, Juneja K B S, Negi B S and Kazmi H M 1972 Family Leguminosae; In: Indian Woods (eds) Ramesh Rao K and Purkayastha S K, The Manager of Publications, Delhi, 3 264-323.

Rawat M S 1965 Bauhinioxylon indicum gen. et sp. nov., a new dicotyledonous fossil wood from India; Proc. 51st and 52nd Indian Sci. Congr. Calcutta 3425 (Abstract).

Ridley H N 1967 The flora of Malaya Peninsula; Vol. 1, Asher, Amsterdam.

Roy S K and Ghosh P 1981 Fossil woods of Anacardiaceae from the Tertiary of West Bengal, India; Palaeobotanist 28-29 338-352.

Schoph J M 1975 Modes of fossil preservation; Rev. Palaeobot. Palynol. 20 27-53.

Smith A G and Briden J C 1979 Mesozoic and Cenozoic palaeocontinental maps; Cambridge University Press, Cambridge.
Smith A G, Smith D G and Funnel M 1994 Atlas of Mesozoic and Cenozoic coastlines; Cambridge University Press, Cambridge.

Spicer R A, Valdes P J, Spicer T E V, Craggs H J, Srivastava G, Mehrotra R C and Yang J 2009 New developments in CLAMP: Calibration using global gridded meteorological data; Palaeogeogr. Palaeoclimatol. Palaeoecol. 283 91-98.

Srivastava G and Mehrotra R C 2010 Tertiary flora of northeast India vis-à-vis movement of the Indian plate; Geol. Soc. India Memoir No. 75 123-130.

Srivastava R and Awasthi N 1996 Fossil woods from Neogene of Warkalli beds of Kerala Coast and their palaeoecological significance; Geophytology 26 89-98.

Su T, Xing Y W, Liu Y S, Jacques F M B, Chen W Y, Huang Y J and Zhou Z K 2010 Leaf margin analysis: A new equation from humid to mesic forests in China; Palaios 25 234-238.

Trivedi B and Panjwani M 1986 Fossil wood of Bauhinia from the Siwalik beds of Kalagargh, U.P.; Geophytology 16 66-69.

Vozenin-Serra C 1981 Les structures ligneuses Neogens du plateau de Di Linh (Sud-Vietnam); Palaeontographica B 177 136-161.

Wheeler E A and Baas P 1991 A survey of the fossil record for dicotyledonous wood and its significance for evolutionary and ecological wood anatomy; IAWA Bull. N. S. 13 $275-332$.

Wheeler E A and Baas P 1993 The potentials and limitations of dicotyledonous wood anatomy for climatic reconstructions; Paleobiology 19 487-498.

Wilf P 1997 When are leaves good thermometers? A new case for leaf margin analysis; Paleobiology 23 373-390.

Willis J C 1973 A dictionary of flowering plants and ferns; Cambridge University Press, Cambridge.

Wolfe J A 1993 A method of obtaining climatic parameters from leaf assemblages; US Geol. Surv. Bull. 2040 1-73.

Wolfe J A and Upchurch Jr G R 1987 North American nonmarine climates and vegetation during the Late Cretaceous; Palaeogeogr. Palaeoclimatol. Palaeoecol. 61 $33-77$.

Woodcock D W and Ignas C M 1994 Prevalence of wood characters in eastern North America: What characters are most promising for interpreting climates from fossil wood; Am. J. Bot. 81 1243-1251.

Zachos J, Pagani M, Sloan L, Thomas E and Billups K 2001 Trends, rythms, and aberrations in global climate $65 \mathrm{Ma}$ to present; Science 292 686-693. 